\title{
The mineral system approach applied to magmatic Ni-Cu-PGE sulphide deposits
}

Stephen J. Barnes ${ }^{1}$, Alexander R. Cruden ${ }^{2}$, Nicholas Arndt ${ }^{3}$, Benoit M. Saumur ${ }^{2}$

${ }^{1}$ CSIRO Mineral Resources Flagship, Kensington, Perth, Western Australia. Steve.barnes@ csiro.au. ${ }^{2}$ Monash University, Clayton, Melbourne, Australia. ${ }^{3}$ Université Joseph Fournier, Grenoble, France. For thematic issue of Ore Geology Reviews, guest editor David Huston.

\section{Abstract}

Most magmatic Ni-Cu-PGE sulphide deposits occur within long-lived magma pathways fed by high degree partial melts of the mantle. Holistic mineral-system analysis for such deposits has some parallels with dominantly hydrothermal systems, but also some important differences.

Major provinces are associated with large volumes of magma erupted at margins of ancient Archaean cratons, and are associated with small intrusions through which large volumes of magmas have passed. There is no demonstrable association with any particular magma type, although in most provinces the ores are found associated with the most primitive available magmas, whatever these may be. Or-bearing intrusions tend to form early in the evolution of the host province, although exceptions exist to this rule, and these intrusions typically account for very small proportions of the volumes of the province as a whole.

Ore deposition is favoured by prolonged high-volume flow over a horizontal floor. This floor may take the form of the base of a channelized sill, tube or blade-shaped dyke, which account for most of the known host igneous bodies to significant ore deposits. Deposition mechanisms may be chemical or physical, but large high-grade deposits require a major component of transported sulphide liquid, initially carried as droplets. Late stage migration of sulphide liquid as gravity currents within intrusion networks, coupled with infiltration and melting of floor rocks, accounts for the common observation in mafic intrusion hosted deposits of cross cutting relationships between massive sulphides, host intrusions and country rocks.

The following set of criteria is proposed in targeting and evaluating Ni-Cu-PGE sulphide systems: 1) nature of magmatism and relationship to pre-existing cratonic architecture; 2) magmatic and structural controls on the development of protracted-flow magma conduits; 3) access to crustal S 
sources at some point along the pathway; 4) favorable intrusion geometry and emplacement style for deposition, reworking and upgrading of sulphide magmas, and 5) favorable structural history and erosional level for preservation and detectability.

These components can be translated into mappable geological criteria. At the predictive targeting scale, the key features are proximity to ancient cratonic boundaries and long-lived, trans-crustal structures, and relationship to voluminous mafic or ultramafic magmatism typically with high $\mathrm{Mg}$ and low Ti contents, but otherwise lacking distinctive characteristics. At the detection scale, there are two distinct approaches: recognition of high volume magma pathways with prolonged flow-through operating at length scales of km based on morphological, petrological, geophysical and structural observations; and identification of the petrographic and geochemical signals of accumulation or extraction of sulphide liquid.

Keywords: nickel, platinum, magmatic sulphides, mantle plumes, igneous intrusions, komatiites

\section{Introduction}

Magmatic Ni-Cu-PGE sulphide deposits are formed by the segregation and accumulation of immiscible sulphide liquid from mafic or ultramafic magmas. The mineral system approach considers the origin of these deposits in the framework of lithospheric-scale processes from the time-honoured perspective of source, fluids, transport and traps. This approach has been applied over many decades in studies of Ni-Cu-PGE sulphide deposits, particular in a series of papers and books by Naldrett (Naldrett, 1989, 1997, 1999c, Naldrett, 2004a, Naldrett, 2005, 2010b, a, Naldrett, 2011), although the terminology has evolved over the years. In essence the approach involves a broader perspective than forensic studies focusing solely on the deposits themselves. More recent incarnations of the approach have incorporated the concept of self-organization within complex systems (McCuaig and Hronsky, 2014). This contribution takes a multi-scale look at the entire set of processes that concentrate metals from background levels in mantle source rocks to economic concentrations in the accessible crust, taking as starting point the "five questions" approach referred to elsewhere in this volume.

The "five questions" of mineral system theory, i.e. geodynamic history and setting, architecture, fluid reservoirs, fluid pathways, and driving forces for transport and deposition (Cleverley et al., 2007, Barnicoat, 2008), although formulated for hydrothermal mineral systems, are potentially applicable to magmatic ores. However, the relative importance of the different questions -- and the extent to which we have the answers -- are significantly different in magmatic vs hydrothermal systems. We therefore take a step back to consider the fundamental components of a mineral system as expounded by Wyborn et al. (1994) combined with the "life stages" model of Naldrett (2011), as follows:

1) Geodynamic and tectonic setting 
2) Source and compositions of the ore-forming silicate and sulphide magmas

3) The magma migration pathway at crustal scale

4) Mechanical and structural mechanisms for focussing magma flow at the deposition ("trap") site

5) Chemical and physical mechanisms for sulphide accumulation and reworking

6) Factors affecting preservation and detectability

In the following discussion, we consider the spectrum of Ni-Cu-PGE deposit types from komatiitehosted extrusive deposits through to deposits hosted within intrusions with essentially basaltic parent magmas. This discussion mostly steers clear of the vastly endowed but highly unusual Sudbury deposits, on the grounds that their association with a giant meteorite impact is unique, but we note some very important generic implications for ore-forming processes. This contribution also avoids the complex topic of stratiform PGE-rich disseminated sulphide layers ("Reefs") in layered intrusions; although these are also magmatic sulphide ores (Naldrett, 2004a, Cawthorn et al., 2005) that form a continuum of chemical compositions with $\mathrm{Ni}-\mathrm{Cu}$ dominant deposits, they require specific process controls beyond the scope of this discussion. However, we do briefly consider marginal disseminated PGE-rich sulphide ores such as the Platreef of the Bushveld Complex that have aspects of both Reefs and Ni-Cu-PGE deposits. The prime purpose of this contribution is to explore how mineral system thinking can be used to develop exploration strategies for world-class mafic and mafic-ultramafic intrusion hosted Ni-Cu-PGE deposits and camps such as Noril'sk-Talnakh, Voisey's Bay and Jinchuan.

\section{Components of a Ni-Cu-PGE sulphide mineral system}

\subsection{Geodynamic history and setting}

The importance of tectonic setting as a targeting criterion for Ni-Cu-PGE sulphide deposits has been recognised for many decades (Naldrett, 1973, 1981, 1999c, Naldrett, 2004a). A consensus had formed by the mid to late 1980s that several major camps were associated with rifted environments where voluminous mafic or ultramafic magmas were emplaced in sedimentary basins containing abundant sulphur-bearing rocks. This consensus drew on the inference that assimilation of crustal sulphur by silicate melt was necessary to form significant volumes of immiscible metal-enriched sulphide melt from mantle derived magmas, and that ore formation required the transport and physical concentration of this melt. The evidence behind this model has been widely published and discussed, e.g., (Barnes and Lightfoot, 2005, Keays and Lightfoot, 2010, Ripley and Li, 2013) and references therein. Further, it has become widely accepted by most workers that the magmas in question were derived primarily from mantle plumes, and in many cases were emplaced into or on top of the crust during the vast, 
cataclysmic magmatic events associated with the first arrival of mantle starting plumes at the asthenosphere-lithosphere boundary (Campbell and Griffiths, 1990, Campbell, 2007). Such events are recognised in the modern and Phanerozoic Earth as Large Igneous Provinces (LIPs). Their ancient equivalents, or at least the scattered and often mangled remnants of them, are found mainly in Proterozoic and Archaean greenstone belts although some near intact Archaean examples such as the Fortescue Basalts are also recognised.

Subsequent observations and discoveries have made it apparent that this picture is too restrictive, and does not account for the tectonic settings of many of the world's major camps and deposits. Whereas magma emplacement into rift basins containing abundant crustal $\mathrm{S}$ can be clearly recognised in some cases, such as the Pechenga Belt of NW Russia (Hanski, 1992, Green and Melezhik, 1999, Skufin and Theart, 2005) and the Duluth Complex deposits of the Mid-Continent Rift of the USA (Ripley, 2014), this association is unclear in many cases that include several major Ni-Cu-PGE camps. The oreforming magmatic episodes in the Cape Smith Belt formed $150 \mathrm{Ma}$ after the initiation of a rifted passive margin (Mungall 2007a). The tectonic setting at Voisey's Bay has been characterised as transtensional (Myers et al., 2008, Saumur et al., 2015) and there is no obvious evidence of a largescale syn-intrusive rift basin. The geometry of ore-hosting intrusions is in many cases more suggestive of locally compressive, transpressive or transtensive environments, as discussed further below in the cases of deposits hosted by small mafic-parented intrusions (Lightfoot and Evans-Lamswood, 2015) . The Noril'sk - Talnakh camp appears to be associated with the changeover from localised grabencontrolled rift-related basaltic volcanism immediately preceding ore formation to a main oreassociated phase of regional flood basalt volcanism with a different depocentre (Krivolutskaya, 2014, Sluzhenikin et al., 2014). Rifting environments have been proposed for major komatiite-associated camps, such as those of the east Yilgarn Craton in Western Australia (Fiorentini et al., 2010c), but recognisable extensional structures in such terranes commonly post-date volcanism (Blewett et al., 2010). No rifting accompanied the emplacement of the Bushveld Complex and the associated Uitkomst Ni sulphide deposit (Gauert et al., 1995). In well-studied Phanerozoic LIPS, crustal extension is observed in some cases; e.g., the North Atlantic or Ethiopian LIPs, where plume emplacement is associated with opening of ocean basins, but in such cases the rifting commonly postdates emplacement of flood basalts (Menzies et al., 1992, Saunders et al., 1997). The Emeishan LIP in southern China (Ali et al., 2010), Muskox-Coppermine in Canada (Kerans, 1983) and probably Siberia as well are characterised by uplift without unidirectional extension. In many LIPS that do display extension, the magmatism is accompanied by the emplacement of vast radial or linear dyke swarms that are not endowed with significant Ni-Cu-PGE deposits (Ernst et al., 1995).

Furthermore, a number of deposits are not manifestly plume-related. Rifting of the continent may have been triggered by the arrival of one or more plumes (Courtillot et al., 1999) but the largest volumes of magma formed during post-plume mantle upwelling below thinning continental 
lithosphere. Compressional settings are implicated in the deposits of the northern Appalachian Belt in Maine (Thompson and Naldrett, 1984), the Svecofennian Raahe-Ladoga and Vammala Belts in Finland (Peltonen, 1995, Barnes et al., 2009, Eilu et al., 2012), Aguablanca in Spain (Ortega et al., 2004, Pina et al., 2006) and possibly Jinchuan in China (Lehmann et al., 2007) among others. However, in the case of deposits caught up in orogenic belts the original tectonic setting is not always clear. The trend of small intrusion-hosted deposits along the southern edge of the Central Asian Orogenic Belt has been attributed to magma sources related to slab delamination associated with continental collision event (Song et al., 2011, Li et al., 2012).

A significant development that unites most of these occurrences has been the recognition of the spatial association of Ni-Cu-PGE sulphide deposits, from major camps to scattered small deposits, with the margins of ancient Archaean cratonic blocks (Begg et al., 2010), regardless of whether these margins are rifted or not. This association applies almost without exception to the world's major camps. (Even Sudbury conforms to this rule although the association in this case can only be coincidental). By common consensus, this association is thought to be related to deflection of the heads of mantle starting plumes, or melts from the plume, towards zones of thin lithosphere at craton margins, where the bulk of melting to form LIPs takes place (Fig 1). Plume deflection (Sleep et al., 2002, Sobolev et $a l ., 2011)$ potentially accounts for the otherwise paradoxical observation that linear belts of plume magmatism and ore deposits, such as the Archaean East Yilgarn Ni province in Western Australia (Begg et al., 2010, Barnes et al., 2012, McCuaig and Hronsky, 2014, Mole et al., 2014) are derived from what start out as "bullseye" point-source thermal anomalies in the deep mantle.

Figure 1. Plume deflection and crustal-scale pathway model.

\subsection{Sources and compositions of ore-forming magmas}

In the case of hydrothermal systems, there is often a fierce debate about the source of the predominantly aqueous fluids that carry and deposit metals. These fluids are characteristically younger than the host rocks to the ore, and substantially out of equilibrium with them, giving rise to alteration haloes that extend well beyond the boundaries of the orebody itself. In magmatic systems, the ores and immediate host rocks ultimately derive from the same fluid, which in this case is the transporting silicate magma.

The metals in magmatic ores are sourced overwhelmingly from the transporting magmas themselves, and hence ultimately originate from the mantle source. In most of the cases noted above, magma sources are generally held to be sub-lithospheric and derived from deep-seated mantle plumes. The evidence is that mineral provinces are commonly associated with magmas that are higher in $\mathrm{MgO}$, and hence hotter, than typical ambient mantle melting products such as MORBs. The maximum temperatures of such anomalous magmas have decreased with time: major Archaean Ni provinces are 
associated with komatiites, early Proterozoic provinces with high-Mg komatiites-derived basalts, and mid Proterozoic and Phanerozoic provinces with picritic and basaltic magmas (Herzberg et al., 2010). Coupled with this change is the evolution from $\mathrm{Ni}$-rich ores with low $\mathrm{Cu}$ in komatiite settings to ores with subequal $\mathrm{Ni}$ and $\mathrm{Cu}$ contents in post-Archaean mafic settings (Barnes and Lightfoot, 2005). Where multiple magma suites are found within the same province, Ni-Cu-PGE ores are characteristically associated with the suite formed by the highest degree of partial melting, for which low Ti content is a reliable proxy, e.g. (Zhou et al., 2008, Godel et al., 2011).

The composition of the ore-forming magma can in some cases be determined directly, from the chilled margins of the magma bodies that host the ore deposits. The most common examples are in komatiite flow hosted deposits, where samples of magma bearing the imprint of ore forming processes can be found in spinifex-textured margins of the host flows, e.g. at Kambalda, WA (Lesher, 1989, Arndt et al., 2008, Barnes et al., 2013a). In most cases, including komatiites, host rocks are predominantly cumulates: rocks formed by accumulation of liquidus crystallisation products. The composition of cumulates differ significantly from the composition of the parent magma itself, having higher $\mathrm{MgO}$ and lower contents of incompatible elements. In most cases the magma composition can only be inferred from these cumulates, or from magmas sampled in the outflow zones of the orebearing pathways. The main conclusion from such studies is that the range of compositions of oreforming magmas is very wide (Figure 2), ranging from highly magnesian komatiites with $\mathrm{MgO}$ contents as high as $30 \%$ through komatiite-derived basalts $(\mathrm{MgO} 12-18 \%)$ to relatively fractionated tholeiites with $\mathrm{MgO}$ contents well below 10\% (Arndt et al., 2005). The parent magmas to Voisey's Bay crystallised olivines in the 70-80 mol\% forsterite range, implying highly fractionated magmas with $\mathrm{MgO}$ less than 6\%, 250-300 ppm Ni and highly depleted PGEs (Lightfoot et al., 2012). In the anomalous case of Sudbury, Ni-Cu-PGE ores formed from a melt sheet of bulk granodioritic crustal composition with an estimated Ni content below 100 ppm (Lightfoot et al., 1997a, Arndt et al., 2005). A key factor here is that the partition coefficient for Ni from silicate into sulphide liquid increases rapidly with falling temperature and $\mathrm{MgO}$ content, such that Ni-rich sulphides can still form from relatively cool, Ni-poor magmas (Rajamani and Naldrett, 1978).

Zhang et al. (2008) and Griffin et al. (2013) have proposed that LIPs containing magmatic sulphide mineralisation have distinctive geochemical characteristics, and attribute this to the involvement of a metasomatic component in the sub-continental lithosphere. This issue has been debated by a number of papers (Fiorentini et al., 2010a, Arndt, 2013). In the data presented in Figure 2 we find no evidence for systematically "fertile" magmatic provinces or magma types for Ni-Cu-PGE sulphide deposits, and parent magma compositions for ore deposits fall well within the typical range of compositions for plume-related magmas whether the parent magmas are mineralised or not. Griffin et al. (2013) claim anomalously high PGE contents (specifically Os) in "fertile" LIPs. This can be tested in Figure 2 using both Pt and Ir data (Ir correlates very strongly with Os in all magmatic settings, but Ir data are 
much more abundant for reasons related to analytical technique). No evidence is seen for any systematic difference in magma compositions between mineralised LIPs (Siberia, Emeishan) and other examples that are not known to contain significant Ni-Cu-PGE deposits. Furthermore, we find very little evidence within a comprehensive compilation of mantle melt compositions for magmas with primary Pt or Pd contents greater than about $20 \mathrm{ppb}$, the typical values for komatiitic basalts which are the most Pt-Pd enriched magmas known (Fiorentini et al., 2010a), the only exceptions being a small number of boninite samples. Based on our knowledge of partition coefficients and the basic principle of mass conservation (Campbell and Naldrett, 1979, Campbell and Barnes, 1984, Mungall, 2007c, Mungall and Brenan, 2014), there is no need to appeal to exotic magmas to explain any of the range of Ni-Cu-PGE sulphide deposits, or indeed most Reef style PGE deposits.

This said, extensive compilations of data on olivine compositions have raised the possibility that certain mantle melts, specifically those formed from olivine-free plume sources containing a high proportion of recycled oceanic crust, may have elevated Ni contents (Sobolev et al., 2005, Sobolev et al., 2007) owing to a predominance of pyroxene rather than olivine in the source. Such melts have compositions similar to the ferropicrites that are parental to the Pechenga deposits (Hanski et al., 2001), and potentially a number of other important deposits such as Jinchuan (Tonnelier et al., 2009) and Mirabela (Barnes et al., 2011b).

The presence of voluminous, high-temperature melts from a sub-lithospheric source (with the exception of Sudbury) is clearly essential, and mantle plumes remain the most likely source for many deposits. Within any given province, mineralisation is commonly associated with the highest degree partial melts, the least fractionated magmas, and with the most adcumulate rocks (i.e. those containing the highest proportion of cumulus minerals to intercumulus trapped liquid) in conduit systems. In mafic-parented systems such as Noril'sk-Talnakh, the clearest proxy for fertile magmatic environments is the presence of olivine $+\mathrm{Cr}$-spinel cumulates .

Figure 2. Compositions of magmas from LIPs and estimated ranges of compositions of parent magmas to ore deposits.

\subsubsection{Compositions of magmatic sulphide liquids}

As has been well established, bulk compositions of magmatic ore deposits are determined by two major factors: the composition of the associated silicate magma, and the relative volumes of silicate and sulphide liquid (termed the "R factor") that equilibrate with one another (Campbell and Naldrett, 1979). High-Mg, Ni-rich, Cu poor komatiite magmas give rise to ores with high $\mathrm{Ni} / \mathrm{Cu}$ ratios and a wide range of Ni and PGE tenors, whereas mafic magmas formed by lower degrees of partial melting have lower $\mathrm{Ni} / \mathrm{Cu}$, higher ratios of $\mathrm{Pt}+\mathrm{Pd}$ to $\mathrm{Ir}+\mathrm{Os}+\mathrm{Ru}$, and a similarly broad range in tenor (Barnes et al., 1985, Barnes and Lightfoot, 2005). Lower MgO mafic magmas are commonly PGE 
depleted owing to the retention of sulphide liquid in the residue of melting in the mantle, coupled with the extremely high partition coefficients of the PGEs into sulphide liquid. An example is the low Pt content of Hawaiian basaltic magma (Ireland et al., 2009) evident in Figure 2. (The high $\mathrm{Mg}$ compositions of rocks in this data set are due to the presence of entrained olivine phenocrysts, which also accounts for the relatively minor depletion of Ir compared with strong depletion in Pt). Where mineralised, such magmas give rise to ores with normal $\mathrm{Ni}$ and $\mathrm{Cu}$ contents but relatively depleted in PGE contents. Optimal Pt and Pd tenors are found in ores arising from a particular combination of factors: the generally incompatible behavior of $\mathrm{Pt}$ and $\mathrm{Pd}$, resulting in enrichment during fractionation (Figure 2); high enough degrees of partial melting such that these magmas are no longer sulphide saturated in the mantle or during normal fractional crystallisation processes; and physical environments favoring effective entrainment and mixing of the immiscible liquid components and hence high R factors (Naldrett, 2004a, Barnes and Lightfoot, 2005).

The confirmation by Mungall and Brenan (2014) of extremely high (order of $10^{5}-10^{6}$ ) partition coefficients for the PGEs challenges a common assumption about compositions of sulphide liquids: that PGE-deleted magmas necessarily make PGE-poor sulphides. Where all other factors are equal this is true, but simple consideration of R-factor shows that this is too simplistic. An extremely depleted tholeiite, such as the typical Nadezhinsky Formation tholeiites at Noril'sk with $\sim 0.1 \mathrm{ppb} \mathrm{Pt}$, would be in equilibrium with a sulphide liquid having about $1 \mathrm{ppm} P t$ at an $\mathrm{R}$ value of 10,000 and 10 ppm at an R factor of 100,000. For a typical MORB magma, with 1 ppb Pt, sulphide liquid would contain around 10 ppm of Pt at R of 10,000; such concentrations have indeed been observed in sulphide droplets in magmas from the Mid-Atlantic Ridge (Kamenetsky et al., 2013), and would be regarded as exceptionally high tenor if found in orebodies. Of the controls mentioned above, $\mathrm{R}$ factor is by far the dominant control, but the kinetics of reaction between sulphide liquid and magma may be of great importance in determining the effective value (Mungall, 2002).

High magma volumes are essential to the formation of the extremely PGE rich sulphides of the Noril'sk-Talnakh camp, and provide a critical constraint on the ore forming process. Naldrett (1997, 1999b) and Naldrett et al. (1999) have proposed a more complex model than the conventional singlestage batch equilibrium process described by the $\mathrm{R}$-factor equation. In this model, the $\mathrm{Ni}, \mathrm{Cu}$ and PGE contents of pre-existing sulphides are continuously upgraded by interaction with magma flowing past the original site of deposition. In a later variant on this model (Li et al., 2009) the Noril'sk ores are held to have formed from unusually PGE-enriched magmas that had resorbed pre-existing PGErich sulphides at depth. We note here that anomalously PGE-enriched magmas, with Pt or Pd greater than $20 \mathrm{ppb}$, have as yet not been directly observed anywhere in nature (Fiorentini et al., 2010a ). Mungall (2014) has argued that the Noril'sk ores can be explained by derivation from the relatively primitive Tuklonsky Picrite magma without the need to appeal to exotic PGE enriched magmas. 
Additional complexity results in mafic-hosted deposits from the wide temperature range over which $\mathrm{Cu}$-rich sulphide liquid can exist, and the consequent tendency of large sulphide magma pools to differentiate into Ni-rich monosulphide solid solution (MSS) cumulates and more $\mathrm{Cu}, \mathrm{Pt}$ and $\mathrm{Pd}$ rich residua (Naldrett et al., 1982, Li et al., 1996, Mungall, 2007b). This process is involved in the generation of the extreme PGE enrichment in ores of the Kharealakh Intrusion at Talnakh, and in the PGE- and Cu-rich footwall veins at Sudbury.

\subsubsection{Size of magma systems, mantle sources and timing of mineralisation within igneous} provinces

The size of the mantle source is potentially an important issue for the size of the mineral systems and the dimensions of any mineral camp likely to be formed. The sizes of plume-related large igneous provinces (LIPs) are characteristically colossal: as much as $2000 \mathrm{~km}$ across, representing several million $\mathrm{km}^{3}$ of magma, of which only a minute proportion is known to be associated with ores. Given reasonable estimates of $10-20 \%$ partial melting to produce these magmas, the mantle sources themselves must have had volumes of tens of millions of $\mathrm{km}^{3}$ (Coffin and Eldholm, 1993). Such provinces are short lived (typically 1-2 Ma) products of cataclysmic melting of plume heads as they first impinge on the base of the lithosphere (Campbell et al., 1989, Richards et al., 1989, Campbell and Griffiths, 1990). Magmatism associated with the plume tail can be much more prolonged, but is also much more localised: the thermal anomaly associated with the long lived Hawaiian plume is approximately $100 \mathrm{~km}$ across, and has operated continuously for over 80 million years (Tarduno et al., 2003). Hence, from the point of view of scale, it is important to know whether ore camps are associated with plume heads or plume tails, or with plumes that do not fit the simplified "mushroomshaped" image (Fig. 1a), or indeed with other magmatic environments that are nothing to do with plumes at all. The critical evidence here is linked to the timing of mineralisation in relation to the chronology of the province as a whole, and there is no consistent picture.

In some cases of mineralisation in LIPs, notably the Noril'sk-Talnakh deposits, ore formation is exactly coeval with short-lived LIP magmatism (Campbell et al., 1992) relatively early in the sequence. Nickel mineralisation is associated with the East Yilgarn komatiites at $2705 \mathrm{Ma}$, at the beginning of a $20 \mathrm{Myr}$ span of greenstone belt volcanism and a $60 \mathrm{Myr}$ span of magmatism overall (Blewett et al., 2010). Hence, while an association with plume arrival events is indicated on the basis of the regional scale of magmatism, in most cases except Noril'sk the duration of magmatism is somewhat greater than the 1-3 Ma characteristic time of LIPs, and mineralisation can occur either early or late. A long-lived plume tail may be involved, or other processes may be implicated.

Delamination of dense melting residua and consequent upwelling of asthenospheric mantle has been suggested by some authors (Bédard, 2006, Song et al., 2011). More plausibly, the standard "mushroom-shaped" tail and head plume model is over simplistic, particularly for plumes containing 
a substantial component of dense eclogitic material (Sobolev et al., 2005, Sobolev et al., 2007, Sobolev et al., 2011). In other cases, magmatism is more protracted than can be considered for a conventional LIP. The Musgrave province in Central Australia records almost 100 million years of continuous magmatism (Smithies et al., 2011), with a culmination in activity represented by the 10761078 Ma Giles Complex component of the Warakurna LIP (Seat et al., 2007, Seat et al., 2011). The ore-forming Nebo-Babel intrusion is several million years younger at ca. $1068 \mathrm{Ma}$ than the peak of the LIP, occurring at the very end of the prolonged magmatic episode. Magmatism within the midcontinent rift LIP in the central USA spans 10-20 Myr from $1110 \mathrm{Ma}$, with the mineralised Eagle and Tamarack intrusions at 1105-1107 Ma and the main mass of the Duluth Complex at $1098 \mathrm{Ma}$ (Miller et al., 1996)(Keays and Lightfoot, 2015, in press). Voisey's Bay has a zircon and baddeleyite age of ca. 1333 Ma lying towards but not exactly at the start of the 60 Myr span of the 1350-1290 Ma Nain Plutonic Suite (Amelin et al., 1999, Ryan, 2001). In some of these cases a parallel can be drawn with the North Atlantic magmatic province, where LIP-related flood volcanism at $62-55 \mathrm{Ma}$ was followed by more protracted volcanism related to continent rifting and opening of the ocean basin (Saunders et al., 1997). This timing suggests that the mineralisation may be related to high-volume magmatism associated with lithosphere rifting which followed the impingement of the mantle plume. Overall, there is a tendency for mineralised intrusions to be emplaced early in the history of the host province, consistent with plume-head arrival, but this is not an entirely consistent or predictive relationship.

In the case of Noril'sk, the disposition of ore forming intrusions is much smaller than the size of the LIP as a whole, and according to some (but not all) authors is controlled by the architecture of a longlived mantle-tapping fault, the Noril'sk-Karealakh structure (Naldrett and Lightfoot, 1999, Naldrett, 2004e, Sluzhenikin et al., 2014). This leads to the conclusion that, from a targeting perspective, architecture is more important than the size of the ultimate fluid source. That said, where mineralisation is coeval with a LIP event, then any part of that LIP has potential to host mineralisation, provided that long-lived magma conduits exist.

\subsubsection{Sources of sulfur and transport of sulphide liquid}

In all but a small handful of deposits (e.g. Seat et al, 2010), S isotopic evidence strongly attests to the role of assimilated crustal $\mathrm{S}$ in formation of Ni-Cu-PGE sulphide deposits (Ripley and $\mathrm{Li}, 2003$, Keays and Lightfoot, 2010, Ripley and Li, 2013). This is particularly evident in the case of deposits associated with high $\mathrm{T}$ magmas such as komatiites (Bekker et al., 2009); these magmas have $\mathrm{S}$ contents well below the sulphur content at sulphide liquid saturation (SCSS) in their deep mantle sources, and become more undersaturated on ascent owing to the negative correlation of SCSS with pressure (Mavrogenes and O'Neill, 1999).

From a mineral system perspective, the question of proximity of a sulphur source remains one of the major issues in targeting and exploration. The experience of the exploration industry in recent decades 
is that the presence of proximal S-rich sediments is at best a weak indicator of prospectivity. Several important deposits are found in almost completely S-barren country rocks, e.g., Jinchuan (Lehmann et al., 2007, Song et al., 2012); or several km from an isotopically identifiable source, e.g., Voisey's Bay (Li and Naldrett, 2000). The explanation for this probably lies in the mechanism and direction by which sulphide droplets are transported, and the relative difficulty of amalgamating and depositing them, a point to which we return. Even where S-rich country rocks do exist in immediate proximity to host intrusions, and a strong match in $\mathrm{S}$ isotopic composition exists between ores and country rocks exists as at Noril'sk (Naldrett et al., 1992), there are substantive arguments about whether the locally derived $\mathrm{S}$ is the sole or even the most important component in the overall evolution of the mineral system (Wooden et al., 1992, Wooden et al., 1993). At Nori'sk, Ripley et al. (2003) have pointed out that the basalts supposedly related to the ore forming intrusions have $\mathrm{S}$ isotopic composition close to mantle values and do not mimic the heavy evaporate-like signatures seen in the orebodies.

Interpretation is complicated by the mass balance effect whereby isotopic signatures, particularly of Os, become dominated by the pristine mantle component at high values of silicate to sulphide mass ratio, i.e., in high metal tenor ores (Lesher and Burnham, 2001), and by the potential for postmagmatic re-equilibration of $\mathrm{S}$ isotopes between ores and host rocks.

The mechanisms by which sulphide liquid is transported from a site of assimilation remain poorly understood and are one of the more neglected areas of study in these systems. Current models for a number of important deposits attribute the initial segregation of sulphide liquid to deep seated processes, occurring in the lower crust well below the eventual level of formation of the actual deposits, followed by entrainment, upward transport and mechanical deposition. For example, models of this type have been invoked for Voisey's Bay (Lightfoot et al., 2012, Saumur et al., 2013), Jinchuan (Tang, 1991, Song et al., 2012), Eagle (Ding et al., 2012e) and Norils'k-Talnakh (Arndt et al., 2003, Li et al., 2009) (Fig. 1d). These models are prompted largely by the fact that the deposits are all characterised by a vast excess of sulphide and chalcophile metals over that which could originally been dissolved in a body of magma of the dimensions of the host intrusion, and in some cases by evidence that parent magmas had undergone a previous episode of sulphide extraction manifest as PGE depletion (Naldrett, 1992, Lightfoot and Keays, 2005, Song et al., 2012). Sulfur isotope data provide an independent line of evidence. In a number of well-documented cases, notably the Eagle deposit in the USA (Ding et al., 2012a, Ding et al., 2012e), the S isotopic composition of the ores coupled with a lack of matching crustal $S$ in adjacent country rocks require that the sulphide liquid component be introduced from a distal source on a scale of $\mathrm{km}$. Hence, ore formation requires some process of initial segregation of the ore component, followed by remobilisation and mechanical transport to the site of ore deposition.

Traditionally, the site of initial accumulation of sulphide liquid has been placed deep in the crust, and transport has been assumed to be from this deep level upwards to a shallower site where the sulphide 
was deposited to form the ore deposit. This hypothesis must be reconciled with the known physical characteristics of sulphide and silicate liquids. Sulphide ore magmas are very dense compared with silicate magmas, typically over $4000 \mathrm{~kg} / \mathrm{m}^{3}$ (Dobson et al., 2000) compared to $2600 \mathrm{~kg} / \mathrm{m}^{3}$ (McBirney and Murase, 1984) and entrainment of significant proportions of sulphide will substantially increase the density of the suspensions. There are limits on the proportions of sulphide liquid that can be transported vertically by buoyancy-driven flow of magmas through the crust: the simple calculation in Figure 3 shows that if the proportion of suspended olivine is greater than about $15 \%$ by mass, or $10 \%$ with an additional $5 \%$ sulphide liquid, the density of the suspension exceeds that of normal crustal rock. The high density of sulphide liquid would be expected to impede the continuing entrainment and upward transport of sulphide liquid, once it had segregated at depth. However, if the total amount of sulphide is less than about 5\% and if the sulphide liquid is entrained as finely dispersed droplets, Stokes Law settling velocities would be less than typical trans-crustal magma ascent rates. From consideration of the physics of droplet interactions, it is unlikely that significant coalescence of droplets occurs during transport, and droplet breakup is far more likely owing to the combination of shear, gravitational and surface tension forces acting on the droplets (de Bremond d'Ars et al., 2001, Barnes et al., 2013c, Robertson et al., 2015a). Furthermore, the bulk of the sulphide found in most disseminated deposits occurs within a droplet size fraction considerably less than $1 \mathrm{~mm}$ diameter, which would be readily entrained during typical vertical magma flow rates (Robertson, 2015a). This further reinforces the notion that high flow rates in dynamic conduits are essential components of any $\mathrm{Ni}-\mathrm{Cu}-\mathrm{PGE}$ sulphide mineral system, but makes the problem of deposition larger.

Figure 3 densities of suspensions

An alternative interpretation of sulphide transport is that the sulphide liquid accumulates by sedimentation of transported droplets higher in the magma conduit, then subsequently flows downwards to its site of deposition as sulphide liquid + crystal + magma gravity currents. The essential feature of this model is the presence of sloping floors in parts of any magma chamber or conduit. We discuss the implications of this mechanism further below.

\subsection{The magma migration pathway at crustal scale.}

Mafic magmas, and especially ultramafic magmas (komatiites) are dense, in many cases denser than typical continent crust. This raises the question of how they pass through the crust to form lavas and high-level intrusions. The only two driving forces that are available on the right time and length scales for magma movement are buoyancy of the magma column (Lister and Kerr, 1991) and volatile fluid overpressure, of which the second can be disregarded. Apart from extremely low-degree partial melts such as kimberlites and carbonatitites, where the dominant volatile is $\mathrm{CO}_{2}$, and possibly some unusually hydrous supra-subduction zone melts such as boninites, volatile contents of mantle melts 
are an order of magnitude below their solubilities at all but very shallow crustal levels. This is particularly true of high-degree melts typical of mantle plumes; these melts are characteristically very dry (Herzberg and Ohara, 1998). Hence, the only mechanism for transporting high-MgO melts to the shallow crust is through buoyancy. This ascent takes place through dyke propagation, as the buoyancy forces and associated over pressure at the tips of dykes are sufficiently large to drive upward crack propagation (Lister and Kerr, 1991). Ascent of large magma volumes through established crack networks requires a long-lived, continuous supply of magma; such conditions are met by wholesale shallow melting of heads of mantle plumes, accounting for the association of Ni-Cu-PGE sulphide deposits with LIPs; and also favorable structures that may aid crack propagation (Fig. 1). The rifted edges of old lithospheric blocks provide settings where deep, Moho-penetrating faults are available for reactivation, and where dense mafic underplated material is likely to be present at the base of the crust.

At a finer scale, and at higher levels, it is necessary to translate this broader geometry into a setting whereby magma can be channelised into conduits. This brings us to one of the fundamental processes in all mineral systems: focusing the fluid, which in this case is the magma.

\subsection{Intrusion geometry, magma focusing and emplacement mechanisms at deposit scale}

If there is a single unifying factor among all Ni-Cu-PGE sulphide deposits, it is that they are hosted within environments of protracted flow-through of magma. High magma fluxes and prolonged flow within magma conduits are advantageous for several reasons: they provide ideal environments for extensive assimilation of wall rock and crustal sulphur; they allow for significant conduit geometry modification by thermal-mechanical erosion; they potentially concentrate large volumes of originally dispersed sulphide droplets into a small space of potential ore grade and tonnage; and they facilitate the reaction of transported sulphide with large volumes of magma giving rise to high magma to sulphide melt ratios and hence high ore tenors. In many cases, the effects of prolonged flow and high flow rates are similar, and it may be hard to determine whether flow rate or flow duration is the more important, but high flux is crucial for extensive erosion of wall rocks, a common feature in many mineralised intrusions. Critically, however, high-flux or protracted flow pathways, as preserved in intrusions, typically represent a minute proportion of the total volume of a LIP: approximately one part per million in the case of the Noril'sk mineralised intrusions.

The geometry of mafic intrusions, mineralised or otherwise, is a consequence of the interplay of many factors. Principal among these are the structure of the crust (stratified or homogeneous, distribution of fractures and other zones of weakness), far-field stresses related to regional tectonic setting; near-field stresses interacting with buoyancy forces at the propagating tips of magma-filled cracks; exploitation of pre-existing structures; conduit geometry modification by thermal-mechanical erosion; and the 
interplay between crystallisation rates, flow rates and rates of country rock melting and assimilation. In this section we summarise the characteristic geometries of magma transport networks, and then of ore-hosting intrusions, and consider the balance of processes that may form them.

\subsubsection{Magma propagation, networking and vertical growth mechanisms}

The first-order architecture of a magma transport network arises from the propagation and linkage of dykes and sills as magma transport interacts with local crustal structure (Kavanagh et al., 2006, Menand, 2008, Bunger and Cruden, 2011). A critical element for an established melt transport network is that it must be amenable to reopening and exploitation by subsequent magma pulses (Marsh, 2004). Key elements in development of the network are 1) the transition whereby dykes reorient into sills; 2) emergence of dykes from sills; and 3) interaction of propagating dykes and sills with existing mechanical anisotropies (fractures, foliations, lithological contacts). Complex stairstepping geometries can develop when dykes propagate through country rock containing multiply oriented pre-existing anisotropies (e.g. faults and foliations) and syn-intrusive arrays of fractures that are associated with dyke propagation-induced damage. The mineralised dyke-sill complex at Voisey's Bay is an example of such a network. The Eastern Deeps chamber and associated feeder dyke network at Voisey's Bay has been linked to structurally controlled floor depression associated with evacuation of a lower staging chamber (Cruden et al., 2008, Saumur and Cruden, 2015), with dyke geometries showing a strong control by pre-existing structures (Fig. 4).

Figure 1. Model for structurally-controlled emplacement as exemplified by the Discovery Hill Dyke at Voisey's Bay-(Saumur et al., 2015)

Extensive arrays of stacked saucer-shaped and or tabular sills linked by dykes are commonly formed where LIP-scale volumes of mafic magma are injected into thick sedimentary basins (Elliot et al., 1999, Hansen and Cartwright, 2006, Galland et al., 2009). Maps of the poorly outcropping intrusions of the Siberian LIP show widespread development of saucer shapes (e.g. Yakubchuk and Nikishin, (2004). These geometries depend upon the mechanics of shallow intrusion, interaction of the transport network with the Earth's surface, and space creation by roof lifting (Galland et al., 2009, Bunger and Cruden, 2011). Empirically, such saucer-shaped intrusions are highly unfavourable as hosts to major deposits.

The processes of roof uplift and floor depression, and hybrids in between (Cruden, 1998), can account, at least in part, for space creation in some mineralised mafic-ultramafic intrusions. Crucially, however, the elongate ribbon-like "chonolith" intrusions of the Noril'sk-Talnakh camp (Czamanske et al., 1995, Sluzhenikin et al., 2014) have margins that truncate layering in the host sediments, and have evidently created their own space. This relationship appears to be an essential feature of ore-bearing intrusions. 


\subsubsection{Geometries of mineralised intrusions}

Ore-hosting magmatic bodies come in a wide variety of shapes and sizes (Fig. 5): feeder channels to vast komatiite flow fields such as the Kambalda camp, Perseverance and Mt Keith (Lesher et al., 1984, Barnes et al., 2011a); channelised subvolcanic sills such as Noril'sk and Nkomati/Uitkomst (Fedorenko et al., 1996, Gauert et al., 1996, Naldrett and Lightfoot, 1999, Maier et al., 2004) (Fig. $5 a)$; feeder dykes linking vertically separated small tabular intrusions as at Voisey's Bay (EvansLamswood et al., 2000, Lightfoot et al., 2012); tube-like conduits such as Nebo-Babel and Limoiera (Seat et al., 2007, Mota-e-Silva et al., 2013) (Fig. 5b); boat-shaped flares in cumulate-rich dyke-sill transitions such as Eagle, Tamarack, Huangshandong and Kalatongke (Ding et al., 2012a, Li et al., 2012, Gao et al., 2013, Xia et al., 2013, Lightfoot and Evans-Lamswood, 2015, Taranovic et al., 2015) (Fig. 5 c,d); and sword-blade shaped dykes with ultramafic cumulates at the bottom edge, as exemplified by Savannah (formerly Sally Malay) in Western Australia (unpublished data) and the intrusions of the Expo-Ungava South Raglan trend in the Cape Smith Belt, northern Quebec (Mungall, 2007a) (Fig. 5e).

Of the various geometries of host igneous bodies, the simplest and best understood are komatiite lava pathways; the most complex are the variants on sill-dyke transitions in mafic magmatic provinces. Some of the characteristic differences and similarities between such systems are listed in Table 1.

Much exploration attention has been given in recent years to genuinely tube-like chonoliths, examples being the Nebo-Babel intrusion in the Musgrave Province of Western Australia (Seat et al., 2007), Nkomati/Uitkomst (Maier et al., 2004) and the Limoeiro Complex in Brazil (Mota-e-Silva et al., 2013). The mineralised bodies at Noril'sk and Talnakh are considerably broader than they are thick, and are more ribbon-shaped than tube-shaped (Fig. 5). The host bodies at Eagle, Kalatongke and Haungshandong have tube-like chambers (Lightfoot and Evans-Lamswood, 2015) but also have dykelike keels, implying that they may have formed by lateral flow in flared dykes, or perhaps may be themselves a variant type of blade-shaped dyke as discussed below. The Expo-Savannah and EagleKalatongke type geometries in Figure 5e may well form a continuum. Lightfoot and EvansLamswood (2015) point out that many small ore-hosting intrusions have characteristic lozenge-shaped cross sections; they propose that these develop in locally extensional step-overs within regionally transtensive strike-slip faults.

Of the geometries shown in Figure 5, the least widely recognised as hosts to mineralisation are bladeshaped dykes. These are known to occur in shallow volcanic environments, often associated with extension - e.g. Iceland, Hawaii and Ethiopia (Rubin and Pollard, 1987, Lister and Kerr, 1991). They are thought to form when a vertically propagating dyke reaches a level of neutral buoyancy and then starts to propagate laterally, in the circumstance where the minimum compressive stress remains horizontal, in which case there is no incentive for the available excess pressure to form a sill. They 
may also derive from shallow sources at constant pressure, e.g. a subvolcanic magma chamber. In this case, once the lateral extent exceeds the dyke height, magma flow is dominantly horizontal (Rubin, 1995). In the case of the Expo-Ungava deposits, mineralisation is found at the bottom termination of what are clearly blade-shaped dykes; the Savannah deposit and the Eagle's Nest deposit in the Ontario Ring of Fire (Mungall, pers comm., 2015) have very similar geometries, represented in Figure 5e.

Figure 5. Ore-bearing intrusion geometries...

\subsubsection{Self-organising processes in formation of mineralised intrusions}

Flow within long-lived transcrustal dyke and sill networks is likely to be heterogeneous over time, leading to channelised flow. The process is essentially one of self-organisation, involving a positive feedback between high flow rates and reduction of crystallisation rate, as has been well documented in studies of propagating lava flows (Hon et al., 1994). Where thin bodies of flowing magma are emplaced against cold rocks, crystallisation rates are high and the magma body tends to freeze in situ. Flow is then focused into thicker parts of the magma body where solidification is incomplete. Areas of initially slightly accentuated flow rate become attractors to ongoing high flux, a process exemplified by the tendency of rift eruptions to begin as linear fire fountains and to evolve into long lived point eruption sites, such as Pu'u O'o in the current eruption of Kilauea (Mangan et al., 1995, Kauahikaua et al., 1998). This feedback can then be further accentuated by melting and assimilation of country rocks in the floor, walls or roof, as seen in the formation of long erosional lava tubes in basaltic flow fields (Greeley et al., 1998). (Lightfoot and Evans-Lamswood, 2015)Tubular conduits are known to develop early at the propagating margins of individual sills, , providing a potential mechanism for chonolith development (Fig.6a) (Pollard et al., 1975, Miles and Cartwright, 2010, Schofield et al., 2012). Lobate sill margins have been observed by 3D seismic imaging of saucershaped sills in sedimentary basins (Fig. 6b) (Hansen and Cartwright, 2006, Miles and Cartwright, 2010) and are analogous to the marginal lobes of tube-fed lava flows. The formation of lobate sill margins and highly elongate ribbon-shaped sills (Fig. 6c) has been linked to emplacement at shallow depth (low confining pressure) into poorly consolidated sediments (Schofield et al., 2012).

\section{Figure 6. Sill emplacement models....}

The essential characteristic of many mineralised intrusions is presence of discordant relationships with country-rock layering, implying space creation by physical erosion, by melting or otherwise, of country rock, rather than by roof-lifting as for saucer sills. Widening of the conduit by assimilation of wall rocks is a critical factor in development of preferred high flux pathways, owing to self-organising feedback between magma flux, wall rock melting and inhibition of crystallisation in contaminated magmas. Clear evidence for this is seen in the mineralised intrusions at Noril'sk, and at Nkomati 
(Uitkomst) where the sloping lower host intrusions truncate bedding in the country rock sediments. A small intrusion into cold country rocks forms a chilled margin that tends to prevent heat transfer into the country rock at the time scale of intrusion emplacement. If flow is short-lived, slow or intermittent, this will result in formation of single-phase intrusions, potentially showing monotonic internal differentiation, and lacking potential to host orebodies. Where flow continues longer, particularly but not necessarily if the flux is high, the magma can re-melt the earlier chilled margin, bringing hot magma into contact with wall rock (Huppert and Sparks, 1988a). At sufficiently high Reynolds numbers (the ratio of inertial to viscous forces), and particularly where Reynolds numbers are high enough for turbulent flow, the thermal boundary layer between hot magma and potentially fusible country rock becomes very narrow, and melting of the country rock takes over. Owing to the very slow rate of heat diffusion into rock, this process is driven almost entirely by direct contact between magma and wall rock, rather than by an intermediate stage of development of a thermal aureole: melting fronts advance faster than isotherms in the aureole (Gole et al., 2013). The most efficient interaction and conduit widening is likely to take place by mechanical incorporation of detached xenoliths (Robertson et al., 2015e) and by buoyancy-driven ascent of plumes of molten floor rocks at the bottom of the flowing magma. Melting at the roof will be more rapid, and is liable to form a layer of roof melt that may or may not be incorporated into the flowing magma beneath, depending on composition, viscosity and flow rates (Huppert and Sparks, 1988c, Leitch, 2004). Melting at the base may be less rapid but is facilitated by the detachment and upward migration from the floor of relatively buoyant xenoliths or pockets of xenomelt; this process may be enhanced by the presence of sulphide liquid pools, as discussed further below. Intrusion breccias and vari-textured (pegmatoidal) contaminated mafic rocks in direct contact with country rocks are a likely consequence of such interactions, and where they occur in small intrusions they are a strong indicator of high magma fluxes, protracted magma flowage, or erosion by downward-flowing sulphide magmas and/or sulphide-rich slurries.

In dyke settings, jogs with steep sides and gently inclined floors (i.e., funnel shapes) are significantly wider that the main part of the dyke, and some contain significant mineralisation, such as the Ovoid and Mini Ovoid (e.g., Evans-Lamswood et al., 2000; Lightfoot et al., 2012). This widening is also interpreted to occur by thermo-mechanical erosion, after the emplacement of the initial dyke as magma flows though the network. Heat transfer from the dyke into the country rock generates thermal stresses that are sufficient to promote spalling of rock fragments into the flowing magma (Marsh, 2004). Build-up of thermal stresses will be greatest above gently dipping segments of the dyke, and country rock spalling will occur preferentially along pre-existing fractures and fabrics. This process appears to have occurred during emplacement of the Discovery Hill Dyke at Voisey's Bay (Fig. 4), whose geometry in map view and cross section is strongly controlled by pre-existing fractures and a foliation within the country rock (Saumur et al., 2015). 
Conduit widening potentially gives rise to transitions from initially blade-shaped dykes to EagleKalatongke type dyke/tube geometries. We suggest that this relatively common ore-bearing intrusion morphology (Figure 5c,d) may have an origin as blade-shaped dykes that propagating laterally and widen into tubes where the dykes intersect more easily erodible country rocks. If this interpretation is correct, the mineralization in the keels of such intrusions may be filling the basal termination of a laterally propagating blade, rather than occupying the trace of upward injection of magma from a dyke into a funnel, as in the conventional interpretation of these deposits. The lenticular plan geometry of such deposits, Huangshandong being a prime example (Gao et al., 2013), may then be due to the intersection of the erosion surface with the lower portion of a horizontally disposed lenticular blade, as in the Tootoo and Mequillon deposits of the South Raglan trend (Mungall, 2007a).

\subsection{Chemical and physical mechanisms for ore precipitation}

As noted above, orebodies develop within a wide diversity of host magma bodies. It is generally stated in the literature that favorable environments imply some component of horizontal flow, or a change in flow regime leading to lower vertical components of flow rate such as the transition from a narrow dyke to a wider conduit. The precise mechanisms by which sulphide liquid segregates and becomes concentrated into orebodies remain probably the least understood aspect of $\mathrm{Ni}-\mathrm{Cu}$-PGE sulphide mineral systems. Clearly, understanding such mechanisms is critical to formulating predictive exploration models. Deposition of cumulus sulphide liquid can take place by two distinctly different mechanisms: nucleation and growth of liquid droplets from solution in silicate melt, or by some form of mechanical deposition of transported droplets. We further suggest that gravitational instability of accumulated sulphide liquid pools may play a major role in the final distribution of orebodies and the generation of breccia ores.

\subsubsection{Chemical deposition.}

The in-situ nucleation process, which is essentially one of purely chemical precipitation from solution, occurs in response to changing composition or temperature of the host magma, causing the $\mathrm{S}$ content of the melt to exceed that at sulphide liquid saturation. This could be in response to cooling, crystallisation of silicate phases pushing up the $\mathrm{S}$ content of the residual liquid or changes in redox state. Redox driven deposition is unlikely, in that it requires changing the proportions of two of the most abundant constituents of the magma, iron and oxygen, but may be locally important at small scales in some cases. In any of these cases, the result will either be formation of entrained droplets that are transported further in the flowing magma, or co-precipitation with liquidus silicates to form disseminated ores that are likely to have (on average) cotectic silicate to sulphide proportions. The term cotectic here refers to the expected ratio of phases formed by a magma crystallising along its liquidus surface; for magmas with sulphide liquid and olivine or pyroxene on the liquidus, this ratio is 
typically 50-100:1 (Cawthorn, 2005, Barnes, 2007). Such a process has been recognised in some komatiitic cumulates, where distinct populations of cotectically precipitated and mechanically deposited sulphide liquid droplets have been identified (Godel et al., 2013). In plagioclase-saturated systems, the cotectic proportion of sulphide in cumulate assemblages may be much lower, obscuring the traces of sulphide liquid saturated magmas (Cawthorn, 2005). Cotectic disseminated sulphides may in many circumstances be misleading false positives for high-grade ore potential.

\subsubsection{Mechanical deposition of sulphide droplets.}

Mechanical segregation of sulphide droplets is an entirely different process driven by density contrast, and is likely to be enhanced by processes such as coalescence of sulphide droplets, mechanical riffling, rapid changes in flow regime favoring deposition over transport, or kinetic sieving in density currents charged with silicate crystals and sulfide liquid. A critical problem in forming high-grade sulphide-rich ores is that of mechanically segregating and depositing sulphide liquid without simultaneously depositing large proportions of cumulus silicate phases. In a number of low-grade deposits, such as Mirabela in Brazil (Barnes et al., 2011b) and Kevitsa in Finland (Mutanen and Huhma, 2001, Yang et al., 2013), there was no effective segregation of sulphide from cumulus silicates, and tens to hundreds of meters of thickness of high-tenor but low-grade disseminated ores was the result. In both of these deposits the proportion of sulphide liquid in the cumulates is well in excess of the expected cotectic proportion of about 1-2\%. A component of mechanical concentration of sulphide is implied, but an efficient mechanism was evidently lacking in these cases for mechanically segregating sulphide from silicate components, or suppressing silicate crystallisation.

High-grade systems are characterised by the presence of sulphide liquid in very large excess over cotectic proportions. In the case of sulphide-rich basal accumulations in komatiite flows, such as in the deposits of the Kambalda camp, this excess can be explained relatively easily (Lesher et al., 1984). Local derivation of sulphide from thermomechanical erosion of immediately adjacent sulphidic footwall sediments produces a large excess of sulphide liquid; much of this forms by direct melting of assimilated pyrrhotite, rather than by a two-stage process of dissolution and precipitation. The ore metals Ni, Cu and PGE are highly chalcophile and partition strongly into the molten sulphide, potentially producing high tenors. Sulphide is entrained and deposited over relatively small distances, from komatiite lava that is either superheated with respect to the silicate liquidus, or only crystallize relatively small amounts of liquidus silicates (olivine) over large temperature intervals. Any olivine that does co-precipitate with the mechanically deposited sulphide tends to float out of the basal sulphide pools owing to buoyancy, or in cases where the proportion of olivine is high enough forms net-textured or "matrix" ores. These may be driven by the Archimedes effect, the so-called "billiardball" model of Naldrett (1973), or by extensive percolation of interconnected sulphide melt through intercumulus pore space (Chung and Mungall, 2009). The low viscosity of komatiite lava enhances 
the process. In highly dynamic flow channels, sulphide pools may be repeatedly entrained (Robertson et al., 2014), transported and redeposited giving rise to complex ore profiles and variable tenors.

In mafic systems, the separation of sulphide liquid from cumulus silicate phases is hindered by two major factors. Mafic magmas are typically at least an order of magnitude more viscous than komatiites, so the efficiency of segregation of solid and immiscible liquid phases from the host magma is reduced. Secondly, the liquidus slope is typically shallower than for komatiites and the temperature difference between the liquidus and the appearance of the second silicate mineral is less. Hence, a given temperature drop corresponds to a higher amount of crystallisation. Both factors hinder the segregation of sulphide liquid without simultaneous accumulation of silicate phases.

The process by which massive ores segregate from mafic magmas under such conditions remains mysterious. One possible mechanism involves initial deposition of silicate mineral -sulphide droplet slurries, followed by drainage and accumulation of disseminated sulphides through the pore space of mixed silicate-sulphide liquid cumulates. The drawback of this mechanism is that sulphide liquid under most circumstances does not wet silicate phases when interstitial silicate melt is present (Barnes et al., 2008, Chung and Mungall, 2009). Consequently, disseminated ores mostly tend to consist of isolated mm-sized sulphide aggregates with poor interconnectivity (Barnes et al., 2011b, Barnes et al., 2013c, Godel et al., 2013, Robertson et al., 2015a). Where S sources are local, sulphides may be directly assimilated as xenoliths and xenomelts, to be deposited rapidly as large blebs that coalesce rapidly, but many deposits have clearly formed kilometres from sulphide sources, as discussed above, requiring a component of dispersion and transport before accumulation and deposition. Sulphide liquid droplets may be selectively concentrated by mechanical riffling processes along irregular flow channels, at choke points in dykes, or at flare points in dykes where flow rates suddenly drop.

A new possibility recently raised by developments in fluid mechanics is that droplets may be preconcentrated within eddies developed within chaotic laminar flows, to the point where they begin to coalesce and settle as droplet avalanches (Robertson et al., 2014). In such cases, the aggregate density of the droplet-rich suspension becomes the dominant driver, rather than Stokes settling velocities of individual droplets. This is one of the few possible mechanisms that potentially solves the knotty problem of how to segregate sulphide droplets without also segregating silicate liquidus phases, and hence forming massive rather than disseminated ores.

We note in passing that in the case of high-R factor, strongly PGE enriched sulphides, economically viable high-tonnage orebodies may be generated by deposition of relatively small proportions of disseminated sulphides along with cumulus silicates. The prime example of this setting is the Platreef of the northern limb of the Bushveld Complex (Holwell and McDonald, 2006), which is by far the most important example of a class of disseminated PGE-rich sulphide deposits within marginal facies rocks of layered intrusions. The key to the anomalously high PGE contents of deposits of this type is 
the transport and extensive equilibration of relatively low proportions of sulphide liquid droplets (McDonald and Holwell, 2007), possibly during the lateral propagation of the leading edge of a large sill.

The continuum of host intrusion types discussed above (Figure 5) shares a common feature. Ore deposition is favoured by high-volume flow over a horizontal floor. This floor may take the form of the base of a sill, tube or bladed-shaped dyke.

\subsubsection{Redeposition, downward injections and gravitational back-flow mechanisms.}

Where massive sulphide accumulations are found within komatiite lava flows or sills, they are most commonly found at basal contacts. The same relationship is found in many mafic-hosted deposits, but typically relationships are much more complex (Table 1). Massive sulphide bodies are commonly discordant to basal contacts, commonly penetrate into footwall rocks, and in some cases intrude and postdate magmatic layering within their own host intrusion.

Many examples exist of downward penetration of sulphide melts into fractures, bedding planes and breccias within country rocks immediately beneath massive sulphide ores, in both komatiitic extrusive and mafic intrusive settings (Fig. 7). In some of these cases, downward injection gives rise to breccia ores consisting of fragments of silicate country rocks and of host intrusion rocks in a matrix of massive sulphide. The best examples by far of such processes are found at Sudbury.

Figure 7 Downward sulphide injections, various.

The Sudbury deposits are in many respects unique, but they provide some important clues to gravitydriven processes. Firstly, massive and inclusion-filled sulphide veins penetrate wall rocks to depths of hundreds of meters below the base of the Sudbury layered complex where they are driven by the abundance of fractures and the high density and low viscosity of the sulphide melt (Lightfoot et al., 1997b, Lightfoot and Farrow, 2002, Lightfoot and Zotov, 2005). Secondly, massive sulphide accumulations, characteristically with abundant silicate rock fragments, are almost exclusively found at the basal contact, and typically within trough-shaped footwall contact embayments. The key factor here is that the Sudbury body is widely held to have formed from a superheated melt sheet, such that accumulation of sulphide melt droplets took place in the absence of abundant co-precipitating silicate phases (Naldrett, 1999a). The association of the ore embayments and the offset dykes suggests that downward gravity-driven flow of sulphide liquid, essentially as density currents along the floor and into underlying cracks, may have played a major role at Sudbury (Ripley et al., 2015) . Very shallow slopes may have been sufficient to trigger the necessary instabilities, as in the case of sedimentary turbidity currents. 
Underground exposures of breccias and vein systems generated by downward injection of sulphide liquid into footwall rocks are shown in Fig. 7 for a range of deposit types. In the komatiite-hosted Silver Swan deposit (Fig. 7a,b), described in detail by Dowling et al. (2004), sulphide melt penetrated into the footwall as sulphide vein networks, overlain by a mixed emulsion zone formed by molten dacite floating upward into the sulphide pool, creating a basal zone of interconnected silicate melt giving the appearance of a breccia. The process is essentially one of reverse stoping. At Noril'skTalnakh, mine geologists argue that sulphide-charged slurries or pulses of massive sulphide liquid were injected at a late stage into the ore-bearing intrusions, accounting for large scale discordances between massive ore and host-intrusion layering (Czamanske et al., 1995); injections of sulphide liquid into footwall sediments (Fig. 7c) are common at a range of scales (Zen'ko and Czamanske, 1992, Sluzhenikin et al., 2014). Penetration of massive sulphides into pillow breccias and interstices in footwall basalts is a widely recognised feature at Kambalda (Lesher, 1989) (Fig. 7d). Massive sulphides in the Savannah (formerly Sally Malay) intrusion-hosted deposit in Western Australia also form injection breccias, accompanied by downward penetration of metre-scale vertical sulphide dykes into the footwall (Fig. 7f). Saumur (2014) documented evidence of downward sulphide propagation at Voisey's Bay, notably in the Reid Brook Zone where massive sulphide veins, located structurally below bodies of massive sulphide, occur both within the dyke system and along pre-existing wall rock fractures and anisotropies (Fig. 7g). Mineralisation of the Eastern Deeps deposit of Voisey's Bay is largely contained within the intrusion, likely because of the relatively isotropic nature of the surrounding wall rock gneiss (Saumur et al., 2015); nevertheless, meter- to 10m-scale downward propagation of sulphide along grain boundaries in the gneiss immediately below the Eastern Deeps is locally observed. Benko et al. (2015) describe injections of sulphide liquid associated with partially molten wall rocks at depths up to $125 \mathrm{~m}$ below the basal contact of the South Kawishiwi intrusion in the Duluth Complex.

Downward injection of sulphide melt or slurries may operate at a range of scales and on different time scales in mafic systems. A continuous conduit extending vertically provides a passage for high-flux magmas, which move upwards, and dense slurries, which move downwards. Breccias and other indications of interaction with wall rocks, when present near the lower contacts of intrusions, could have resulted from thermo-mechanical erosion by slurries charged with crystals and rock fragments. Alternatively, they could have developed more passively by gravitational flow of dense sulphide into fractured footwall rocks, generating local melting and displacement of silicate melt by sulphide melt by a form of "reverse stoping", as in the Silver Swan and Kharaelakh examples shown in Figure 7.

Cross-cutting relationships where massive sulphide bodies appear to intrude their host bodies may be the result of downward mobilisation of dense sulphide-lubricated density currents derived from the upper side walls or sloping floors of intrusions (Arndt et al., 2013). Such processes would be facilitated in flow-through conduits that remain hot for long periods. Previously deposited sulphide 
pools are highly susceptible to re-entrainment by pulsed flow of magma flowing directly above them (Robertson et al., 2014). Multiple cycles of deposition, downward reinjection, re-entrainment and redeposition may potentially operate within dynamic conduits with a large vertical dimension (Fig. 8). Mixing of sulphide with silicate melt during this process may explain the high $\mathrm{R}$ factors calculated for these deposits and may contribute to the upgrading of ore tenors as observed at Noril'sk (Naldrett, 1997, 1999c, Li et al., 2009).

\subsubsection{Volatiles, taxites and wall-rock interactions.}

A role for volatiles in magmatic systems is indicated by the association of some mafic-hosted deposits with distinctive pegmatoidal mafic units, within intrusions otherwise dominated by dry cumulus assemblages. These rocks are confusingly called by different names in different places: taxites in the Noril'sk Camp, vari-textured rocks at Voisey's Bay and gabbro pegmatites in other places. They are characterised by large fluctuations at decimeter to meter scale from $\mathrm{mm}$ to $\mathrm{cm}$ scale grain size. In some cases they appear to be breccias, with clasts of finer grained material within net-veins of coarser-grained rock. There is also a very common association of sulphide aggregates with late-stage, near-solidus hydrous phases such as phlogopite and pargasitic amphibole. In some cases this association may reflect the orthocumulate character of the host rocks; sulphide liquid and late-stage fractionate trapped liquid are the last phases in the rock to solidify and hence accumulate together as dregs in the last remnants of the porosity (Barnes and Campbell, 1988). This process is selfreinforcing, as the solidus temperature is progressively depressed by addition of volatiles, keeping the pathway open at lower temperatures and hence acting a sink for more migrating fluids. Water added in this way acts as a flux in the final stages of crystallisation, causing the highly localised development of coarse grain sizes. However, volatile phases are widespread in settings such as sulphide ore breccias where this explanation may not be applicable.

Pegmatoidal units are common in many large mafic intrusions where they reflect the escape channelways of residual ultra-fractionated volatile-rich material derived from trapped liquid in the cumulus pile (Barnes, 1986). In the Noril'sk intrusions, however, they occur primarily at the margins (Lightfoot and Zotov, 2014), and are most probably the result of local assimilation of water and other volatiles from the wall rocks during prolonged flow-through, stoping and xenolith incorporation as discussed in a previous section. However, there is a clear association of sulphide ores with taxitic textures. This observation, along with the association of sulphide ores with hydrous silicate phases, in proportions well above those expected from trapped liquid crystallisation, remains a neglected aspect of ore genesis in mafic intrusions in need of further investigation.

\subsubsection{A dynamic model for sulphide ore emplacement in a mafic flow-through sill-dyke system}


Figure 8 presents a theoretical framework for multistage deposition and reworking of sulphides within a vertically and laterally extensive conduit system, drawing on many of the observations and ideas outlined above. The figure represents the development of a series of flow-through dykes and conduits, with a major component of the flow occurring horizontally at right angles to the plane of the image. He basic assumptions are as follows: the geometry of the various intrusive components is controlled by pre-existing cross-structures; the flowing magma contains a component of sulphide liquid droplets derived from a deeper contaminant, although sulphide assimilation may also take place within the high-level conduits themselves; the horizontal components of the system are widened by melting and/or dissolution of country rocks; and the final disposition of the sulphide pools is influenced by gravity-driven backflow and re-emplacement. Initial sites of deposition are controlled by a variety of factors including changeover from vertical to lateral flow; horizontal basal culminations of bladeshaped dykes; slowing flow velocities at chamber entry points; development of localised eddies at bends and kinks in the flow path; and flow barriers at hydraulic jumps in sill-dyke transitions, such as those documented by Bedard et al. (2012) in the Franklin Sills in arctic Canada. The last stage (phase 4) represents the situation where the density of the incoming magma mush exceeds the density of the surrounding crust, resulting in loss of the gravitational driver for vertical ascent. At this stage magma begins to drain back into underlying deeper chambers, resulting in a net flow of magma, crystals and sulphides from the sub-chambers back into the feeder dykes. In this interpretation, sulphide rich accumulations in intrusion keels are formed at this stage by drainage, kinetic sieving and downward emplacement, rather than by droplet settling due to a decrease in flow velocity as in previous interpretations. This type of drain-back process is commonly observed in active volcanic systems such as the East Pacific Rise (Haymon et al., 1991) and Kilauea (Barker et al., 2003), where drain-back commonly occurs in the waning stages of eruptive cycles.

The processes of backflow, re-entrainment and redeposition may occur as multiple cycles within the development of a long lived system. This may account for an otherwise paradoxical observation made by Lightfoot and Evans-Lamswood (2015) that Noril'sk-style ores must have equilibrated with many hundreds or thousands of times their own volume of magma, but appear to have been emplaced late during the emplacement history of the host intrusion. In this interpretation, they may have been recycled many times, allowing them to be upgraded by continuous magma flow as originally proposed by Naldrett (1999b), but the final late stage of gravitational re-injection is the one that is preserved.

Not shown in the figure is the final stage of solidification of the intrusions, which is likely to involve in situ fractionation and internal differentiation of the silicate (and sulphide) melt pools remaining in the intrusions after the flow stops. The key point here is that the final disposition of rock types in a system is a snapshot of what happened last: much of the history of the dynamic, open-system mineralizing stages of the pathway development may be obscured by later static processes. Some mineralised chonoliths may be differentiated, examples being the Noril'sk-Talnakh bodies and the 
Nebo-Babel intrusion (Seat et al., 2007), whereas others may be entirely occupied by relatively homogeneous ultramafic cumulates, such as Tamarack (Taranovic et al., 2015) and (possibly) Jinchuan (Chai and Naldrett, 1992, Lehmann et al., 2007). The difference is due to the thickness of the body of magma in the flow channel at the point where flow ceases, which in turn may be controlled by changes in far-field stress regimes, intrusion depth and other complex factors. The key to crustal scale nickel mineral systems lies in understanding their dynamic and diachronous nature.

Figure 8 Sequential emplacement-backflow model

\subsubsection{Komatiite vs mafic hosted deposits}

At this point we return to a comparison made previously and summarised in table 1. Komatiite-hosted and mafic intrusion-hosted deposits are substantially different in many aspects, but also share a number of commonalities. The essential one is the necessity for prolonged flow-through in a long lived feeder conduit, being major lava tubes or distributor channels in the komatiite case, or chonoliths and/or conduit dyke-sill systems in mafic settings. Some of the critical differences are largely related to the temperature and viscosity of the host magmas, but these are not the only important factors.

Mafic systems are in many cases multi-stage and involve multiple episodes of emplacement and reinjection of sulphide liquid to form cross-cutting breccia ores. While magmatic breccia ores are not unknown in komatiites, they are relatively rare and where they occur appear to have formed by passive melting and incorporation of adjacent floor rocks e.g. at Silver Swan (Dowling et al., 2004) (Fig. 7a,b); sulphide ore breccias in mafic intrusive settings may form the same way.

Viscosity is one of the key differences between komatiitic and basaltic systems, but there are others potentially just as important. Komatiite-hosted systems are volcanic or shallow subvolcanic, so they cool more rapidly, while mafic intrusive systems, being insulated by the surrounding rocks, stay hot for a long time. Hence there is a lot more scope for the sulphide liquid to move around in intrusive settings after it segregates from the magma. Further, there is a substantial difference in the relative melting ranges between sulphide and silicate magmas in mafic vs ultramafic systems (Fig. 9). In komatiites the sulphides are still entirely liquid at the silicate solidus, but solidify over a narrow range, probably less than 100 degrees. In mafic systems there is a large overlap, especially if the mafic magmas are volatile-enriched owing to crustal assimilation. There may be a temperature range of 150 degrees or more where both components are partially molten, and $\mathrm{Cu}$-rich sulphide liquids are still molten and mobile down to $850^{\circ} \mathrm{C}$ or possibly even lower (Craig and Kullerud, 1969, Medard and Grove, 2005). These are much lower solidus temperatures than the Ni rich, $\mathrm{Cu}$ poor sulphides in komatiites. Consequently partially molten silicate and sulphide liquids interact much more extensively in mafic intrusive than in komatiite settings, leading to more complex textural relationships, and a 
much higher probability of producing intrusive/invasive relationships between still-molten sulphide and nearly solid mafic host rocks.

Figure 9 Melting ranges of silicate and sulphide melts at low and high pressure

We suggest that the greater propensity of mafic systems to host cross-cutting breccia ores is due to two major factors: overlapping melting ranges, and the formation of mafic systems as components of extensive trans-crustal magma conduits with a large vertical component. In mafic systems ore formation occurs at multiple levels within magma transport networks of large vertical as well as horizontal extent, whereas ore formation in komatiites is essentially confined to horizontal systems within lava flows, and hence is driven purely by thermal energy. Mafic systems have the additional driver of gravitational potential energy of dense sulphide liquid accumulations.

\subsection{Tectonic remobilisation of sulphide ores}

Magmatic Ni-Cu-PGE sulphide ores commonly occur in terranes that have undergone extensive tectonic deformation, ranging from ductile to brittle conditions, and the weakness of sulphide minerals leads to a strong propensity for strain to be localised within high-sulphide ores . The many forms that such deformed orebodies can take are the consequences of tectonic conditions specific to each example. In environments of very high strain, such as the komatiite-hosted deposits of the Perseverance and Lake Johnston camps in Western Australia (Barnes, 2006, Duuring et al., 2007) or the deposits of the Thompson Belt in Canada (Layton-Matthews et al., 2007), large proportions of the massive sulphide component of the orebodies end up located many hundreds of metres from their original host ultramafic bodies, probably (at least at Perseverance) due to the nucleation of shear zones on original massive sulphide shoots at lithological contacts. Concentrations of massive ore are commonly localised in fold hinges and strain shadows, and ore shoots are typically attenuated on fold limbs. Durchbewegung breccia textures, characterised by "floating" rounded silicate fragments in a sulfide matrix, are common. However, even in high strain zones, there is relatively little propensity for disseminated and matrix (net-textured) ores to be extensively mobilised, and in many cases they show relatively little penetrative deformation even when adjacent massive ores are intensely sheared and mobilised. Relatively little has been published on this aspect of Ni sulphide ores (McQueen, 1979, 1987, Duuring et al., 2007)(Perring, 2015, in press) and much remains to be fully understood.

\subsection{Unroofing and preservation}

An often-neglected aspect of mineral system studies is the chance of an ore deposit being exposed and preserved through long histories of tectonism, uplift, erosion and weathering. Nickel systems can form at a wide range of crustal levels, and in settings having a wide range of tectonic histories. From this point of view, Ni-Cu-PGE sulphide deposits have some advantages over deposit styles such as porphyry and epithermal systems that form at high crustal levels in areas of rapid uplift and 
consequently are highly susceptible to erosion. However, a Ni-Cu-PGE sulphide deposit that forms at few kilometres depth can be mined only if erosion of tectonic processes bring it close to the surface.

The Noril'sk- Talnakh deposits provide an excellent illustration of the principle: the deposits are localised within a long-lived major trans-crustal structure (the Noril'sk-Karealakh Fault) immediately beneath the thickest portion of a vast and mostly flat-lying sequence of flood basalts. Without the presence of two independent anticlinal structures that intersect at the exact basic centre, the deposits would be buried underneath several $\mathrm{km}$ of basalt and might never have been detected (Naldrett, 1999c). There is some evidence that a large amount of sulphide accumulated during the contamination that led to the sulphide segregation recorded by the extreme depletion of chalcophile elements in the Nadezhda basalts (Naldrett et al., 1992) but this deposit is probably buried at depths inaccessible to mining (Arndt et al. 2003; Li et al, 2009). Other comparable deposits may well exist associated with other major flood basalt provinces but are unlikely ever to be detected or exploited. The intrusive complexes beneath older LIPs may be exposed by deformation and these potentially make better targets, but then require a coincidental combination of structure, plumbing system and erosion level. Komatiite-hosted deposits, formed initially at the top of the crust, are typically only preserved in complexly folded and tectonised terranes, introducing another level of complexity to the orebodies. The complexly deformed orebodies of the Thompson Belt in Manitoba are an outstanding example (Layton-Matthews et al., 2007). Exploration strategies clearly need to be informed by erosion level.

\section{Applications to exploration}

Following the mineral systems template outlined in the Introduction, a set of "six questions" can be considered to guide exploration for Ni-Cu-PGE sulphide mineral systems, as follows:

1) Geodynamic setting and relationship to cratonic architecture

2) Relationship to high-degree mantle melts, in most cases of mantle plume derivation

3) Access to crustal $\mathrm{S}$ sources at some point along the high-flux pathway

4) Structural controls on intrusion geometry, and potential for focusing of horizontal magma flow within long-lived, small cross-section magma conduits

5) Favorable intrusion geometry for deposition, reworking and upgrading of sulphide magmas

6) Favorable structural history and erosional level for preservation and detectability

Of these, points 1 and 2 are largely concerned with regional target selection, while points 3 to 5 relate more to detailed target selection and vectoring at the prospect scale (McCuaig and Hronsky, 2000). Point 6 is largely a matter of luck, an essential factor in the origin and detection of all important orebodies. 
The presence of voluminous mantle melts is clearly essential (with the notable exception of Sudbury), and these may come from mantle plumes or zones of rifting at continental margins. Lithosphere architecture guides the ascent of the mantle source and derivative melts, and focuses the passage of melt through the crust. Within any given province, mineralisation is commonly associated with the highest degree partial melts, the least fractionated magmas, and with the most adcumulate rocks in conduit systems. Mineralised provinces are commonly associated with large fluxes of mafic magmas into the deep crust, giving rise to regional positive gravity anomalies, as for example in the west Musgrave province of Western Australia (Smithies et al., 2011). Major regional structures offsetting deep-seated geophysical signals are a critical targeting indicator.

Much remains to be learned about the geometry of mafic intrusions, and the lesson from detailed study of ore-hosting intrusions is that there are many different variants (Lightfoot and EvansLamswood, 2015). Furthermore, many host intrusions are small, and are developed within country rocks containing conductive beds rich in sulphide or graphite, complicating the process of direct ore detection using electromagnetic methods. Geophysical signals are highly variable, and are further complicated by factors such as magnetic remanence in the case of evolved, magnetite bearing mafic rocks. Lithogeochemical anomalies, with some specific exceptions (Le Vaillant et al., 2015), are restricted to immediate host rock bodies e.g. (Lesher et al., 2001). Improved process understanding is therefore needed to be able to detect distal signals of ore forming processes from sparse information in exploration programs. To be of any use, this understanding needs to be able to predict observable, mappable proxies in the field.

\subsection{Detecting dynamic magma pathways}

Many models for the formation of Ni-Cu-PGE sulphide deposits invoke high-flux or prolonged magma flow through restricted pathways. The following features are consistent with such environments.

1. High abundances of cumulate rocks, particularly the presence of coarse-grained cumulates in close proximity to intrusion margins and higher abundances of cumulus minerals than those in other parts of the plumbing system. Olivine and chromite bearing cumulates are positive indicators in many cases.

2. Characteristic tube-like morphologies, forming a continuum with elongate canoe-shaped flared or blade-shaped dykes, in otherwise more convoluted intrusive systems.

3. Evidence for strong interactions with country rocks such as xenoliths (particularly strongly reacted xenoliths showing evidence of extensive melt extraction, as at Voisey's Bay); marginal breccias; pegmatoidal marginal rocks ("taxites") indicating solidification under anomalously high volatile contents from initially dry magmas. 
4. Proxies for anomalously slow magmatic cooling rates in relation to small size of intrusion such as well developed coarse-grained poikilitic textures; extensive thermal aureoles; anomalously low blocking temperatures from geothermometers such as spinel-olivine Fe-Mg exchange; mineralogical evidence for extensive near-solidus trapped liquid reaction such as Ti-rich magnesio-chromite and picro-ilmenite (Barnes and Tang, 1999, Barnes and Kunilov, 2000).

5. Evidence of sulphide liquid fractionation into $\mathrm{Cu}-\mathrm{Pt}-\mathrm{Pd}$ rich and Ni-rich, $\mathrm{Cu}$ poor components, a process that requires environments of slow and prolonged cooling.

\subsection{Detection of sulphide segregation and accumulation processes}

Sulphide assimilation, segregation and accumulation leave distinctive, readily detectable imprints in host rocks and "spent fluids" vented from deposition sites. Multiple overprinting events and the difficulty of relating specific magmas to ore forming events often complicates interpretation. Even some apparently clear associations, such as that between the depocentre of the highly PGE-depleted Nadezhdinsky Basalt suite of the Siberian Traps and the Noril'sk-Talnakh has been questioned by some as a possible red herring (Arndt et al., 2003). However, the following signals have been empirically verified in case studies.

1) Anomalously high or low platinum group element concentrations, detectable in ratios of $\mathrm{Pt}$, $\mathrm{Pd}$ and $\mathrm{Rh}$ to moderately incompatible elements such as $\mathrm{Ti}$ and $\mathrm{Zr}$ (Barnes et al., 1988, Barnes, 1990, Fiorentini et al., 2010a, Barnes et al., 2013a, Heggie et al., 2013);

2) Anomalous (usually depleted) Ni contents of olivines and pyroxenes (Li and Naldrett, 1999, Barnes and Fiorentini, 2012; Bulle et al, 2015).

3) Presence of supra-cotectic proportions of sulphide liquid droplets (Godel et al., 2013); large volumes of purely cotectic disseminated ores do not necessarily imply proximity to highsulphide, high-grade orebodies;

4) Presence of large sulphide droplets in excess of a few cubic $\mathrm{mm}$ and containing elevated $\mathrm{Ni}$ and PGEs; large droplets are unlikely to survive extensive transport at high flow rates and hence are strong and robust indicators of proximity to a reworked pool of sulphide ore magma (Robertson et al., 2015a).

\subsection{Concluding remarks: research and exploration challenges}

A number of substantial research challenges remain. This particularly applies to our understanding of physical fluid dynamic processes, which is still the least understood aspect of this deposit class. The hypotheses presented here are amenable to testing by a combination of detailed field observations and rigorous application of physics as well as chemistry. Particular aspects in need of further research are (in no particular order):

1. The mechanism of emplacement and structural setting of chonoliths and "flared dikes"; 
2. The origin of "taxites" and the association of intrusion hosted sulphides with hydrous silicate phases;

3. The nature and origin of sulphide ore breccias, and the discrimination of magmatic examples from purely tectonic durchbewegung breccias;

4. The significance of textural varieties of disseminated sulphides in indicating proximity to high grade ores;

5. Understanding the critical differences between mineralised and unmineralised intrusions in the same setting;

The last point is especially important. In a number of well-explored camps, mineralisation is very unevenly distributed among apparently similar intrusions. For example, in the Voisey’s Bay camp, the Voisey's Bay intrusion and associated dyke complex hosts a giant orebody whereas the superficially similar Pants Lake intrusion is subeconomic. In the Noril'sk-Talnakh camp, the Kharaelakh intrusions hosts a supergiant orebody, while the otherwise very similar Noril'sk 1 intrusion hosts a relatively minor deposit. A major research and exploration challenge lies in understanding the reasons for these differences, and this requires that we give as much research attention to unmineralised intrusions as to mineralised ones.

A mineral system approach usefully links a wide range of potential prediction and detection tools for what are some of the hardest exploration targets known. The scope for red herrings, false positives and false negatives is large. The summary presented here, drawn from many decades of detailed research, highlights some specific tools and techniques and offers a number of hypotheses for testing. The huge value of deposits such as the Cu-PGE rich ores in Talnakh camp - of the order of hundreds of billions of dollars within a single ore shoot - provides a powerful incentive to develop process understanding to underpin new prediction and detection techniques.

\section{Acknowledgments}

We thank David Huston for the initial invitation to write this review and Stefan Hagemann for editorial handling. The ideas presented here derive from several decades of interactions and discussions with countless colleagues from academia and the exploration industry. Prominent among these have been Tony Naldrett, Jim Mungall, Mike Lesher, Ian Campbell, Peter Lightfoot, Steve Beresford, Jon Hronsky, Reid Keays, Marco Fiorentini, Rob Hill, Martin Gole, Wolfgang Maier, Sarah-Jane Barnes, Ed Ripley, Chusi Li, Dean Rossell and Tony Green. Invaluable fluid dynamic insights have been provided by Jesse Robertson. We thank N. Krivolutskaya, S Sluzhenikin and field trip leaders of the Noril'sk excursion at the $13^{\text {th }}$ International Platinum Symposium for access to the Noril'sk camp, and for permission to reproduce the photograph in Figure 7C. Panoramic Resources NL are thanked for access to the Savannah deposit. Sarah Dowling is thanked for drawing the 
intrusion-style sketches in Figure 4 and Travis Naughton for further drafting. Steve Beresford and Peter Lightfoot provided extremely helpful reviews. SJB is funded by the CSIRO Office of the Chief Executive Science Leader program and NTA received support from the U.S. National Science Foundation Continental Dynamics Program grant 807585. ARC and BMS acknowledge funding from the Natural Science and Engineering Council of Canada, Vale Newfoundland and Labrador Ltd., and Monash University. This is an output of the CSIRO Mineral Resources Flagship.

\section{References}

Ali J.R., Fitton J.G., Herzberg C. 2010. Emeishan large igneous province (SW China) and the mantleplume up-doming hypothesis. Journal of the Geological Society, 167, 953-9.

Amelin Y., Li C., Naldrett A.J. 1999. Geochronology of the Voisey's Bay Intrusion, Labrador, Canada, by precise U-Pb dating of coexisting baddeleyite, zircon, and apatite. Lithos, 47, 3351: http://dx.doi.org/10.1016/S0024-4937(99)00006-7.

Arndt N.T. 2013. The lithospheric mantle plays no active role in the formation of magmatic ore deposits. Economic Geology, 108.

Arndt N.T., Czamanske G.K., Walker R.J., Chauvel C., Fedorenko V.A. 2003. Geochemistry and origin of the intrusive hosts of the Noril'sk-Talnakh Cu-Ni-PGE sulfide deposits. Economic geology and the Bulletin Of the Society Of Economic Geologists, 98, 495- 515.

Arndt N.T., Lesher C.M., Barnes, Stephen J. 2008. Komatiite. Cambridge: Cambridge University Press.

Arndt N.T., Lesher C.M., Czamanske G.K. 2005. Mantle derived magmas and magmatic Ni-Cu-PGE deposits. Economic Geology 100th Anniversary Volume, 5-24.

Arndt N.T., Sobolev S.V., Barnes, Stephen J., Robertson J. Magma dynamics and the formation of magmatic sulfide deposits (keynote). 12th Biennial SGA Conference. Uppsala, Sweden2013. p. 930-3.

Barker S.R., Sherrod D.R., Lisowski M., Heliker C., Nakata J.S. 2003. Correlation between lava-pond drainback, seismicity, and ground deformation at Pu'u 'O'o. U S Geological Survey Professional Paper, 53-62.

Barnes, Sarah-J. 1990. The use of metal ratios in prospecting for platinum-group element deposits in mafic and ultramafic intrusions. Journal of Geochemical Exploration, 37, 91-9.

Barnes, Sarah-J., Boyd R., Nilsson L.P., Often M., Pedersen R.B., Robins B. The use of mantle normalisation and metal ratios in discriminating between the effects of partial melting, crystal fractionation and sulphide segregation on platinum group metals, gold, nickel and copper: 
examples from Norway. In: Prichard HM, Potts PJ, Bowles JFW, Cribbs SJ, editors. GeoPlatinum '87. London: Elsevier Science Publishers Ltd.; 1988. p. 113-39.

Barnes, Sarah-J., Lightfoot P.C. 2005. Formation of magmatic nickel sulfide deposits and processes affecting their copper and platinum group element contents. Economic Geology 100th Anniversary Volume, 179-214.

Barnes, Sarah-J., Naldrett A.J., Gorton M.P. 1985. The origin of the fractionation of the platinumgroup elements in terrestrial magmas. Chemical Geology, 53, 303-23.

Barnes, Stephen J. 1986. The effect of trapped liquid crystallization on cumulus mineral compositions in layered intrusions. Contributions to Mineralogy and Petrology, 93, 524-31.

Barnes, Stephen J. 2006. Komatiite-hosted nickel sulfide deposits: geology, geochemistry, and genesis. Society of Economic Geologists Special Publication, 13, 51-118.

Barnes, Stephen J. 2007. Cotectic precipitation of olivine and sulfide liquid from komatiite magma, and the origin of komatiite-hosted disseminated nickel sulfide mineralization at Mt Keith and Yakabindie, Western Australia. Economic Geology, 102, 299-304.

Barnes, Stephen J., Campbell I.H. 1988. Role of late magmatic fluids in Merensky-type platinum deposits: a discussion. Geology, 16, 488-91.

Barnes, Stephen J., Fiorentini M.L. 2012. Komatiite magmas and nickel sulfide deposits: a comparison of variably endowed Archean terranes. Economic Geology, 107, 755-80: 10.2113/econgeo.107.5.755.

Barnes, Stephen J., Fiorentini M.L., Austin P., Gessner K., Hough R., Squelch A. 2008. Threedimensional morphology of magmatic sulfides sheds light on ore formation and sulfide melt migration. Geology, 36, 655-8.

Barnes, Stephen J., Fiorentini M.L., Duuring P., Grguric B.A., Perring C.S. 2011a. The Perseverance and Mount Keith Ni deposits of the Agnew-Wiluna Belt, Yilgarn Craton, Western Australia. Reviews in Economic Geology, 17, 51-88.

Barnes, Stephen J., Heggie G.J., Fiorentini M.L. 2013a. Spatial variation in platinum group element concentrations in ore-bearing komatiite at the Long-Victor deposit, Kambalda Dome, Western Australia: enlarging the footprint of nickel sulfide orebodies. Economic Geology, 108, $913-$ 33: 10.2113/econgeo.108.5.913.

Barnes, Stephen J., Kunilov V.Y. 2000. Spinels and Mg ilmenites from the Noril'sk 1 and Talnakh intrusions and other mafic rocks of the Siberian flood basalt province. Economic geology and the Bulletin Of the Society Of Economic Geologists, 95, 1701- 17. 
Barnes, Stephen J., Makkonen H.V., Dowling S.E., Hill R.E.T., Peltonen P. 2009. The 1.88 Ga Kotalahti and Vammala Nickel Belts, Finland: geochemistry of the mafic and ultramafic metavolcanic rocks. Bulletin of the Geological Society of Finland, 81, 103-41.

Barnes, Stephen J., Osborne G.A., Cook D., Barnes L., Maier W.D., Godel B.M. 2011b. The Santa Rita Nickel Sulfide Deposit in the Fazenda Mirabela Intrusion, Bahia, Brazil: geology, sulfide geochemistry and genesis. Economic Geology, 106, 1083-110.

Barnes, Stephen J., Robertson J., Godel B. Physical processes in magmatic ore formation: fluid dynamics of sulfide liquid droplets in sulfide-silicate emulsions (abstract). 12th SGA Biennial Meeting. Uppsala, Sweden2013c. p. 944-7.

Barnes, Stephen J., Tang Z. 1999. Chrome spinels from the Jinchuan Ni-Cu sulphide deposit, Gansu Province, Peoples' Republic of China. Economic Geology, 94, 343-56.

Barnes, Stephen J., Van Kranendonk M.J., Sonntag I. 2012. Geochemistry and tectonic setting of basalts from the Eastern Goldfields Superterrane. Australian Journal of Earth Sciences, 59, 707-35: 10.1080/08120099.2012.687398.

Barnicoat A.C. 2008. The mineral systems approach of the pmd*CRC. Record - Geoscience Australia, 1-6.

Bedard J., Naslund H., Nabelek P., Winpenny A., Hryciuk M., Macdonald W., Hayes B., Stiegerwaldt K., Hadlari T., Rainbird R., Dewey K., Girard E. 2012. Fault-mediated ascent in a Neoproterozoic continental flood basalt province, the Franklin sills, Victoria Island, Canada. GEOLOGICAL SOCIETY OF AMERICA BULLETIN, 124, 723-36: 10.1130/B30450.1.

Bédard J.H. 2006. A Catalytic Delamination-Driven Model for Coupled Genesis of Archaean Crust and Sub-Continental Lithospheric Mantle. Geochimica et Cosmochimica Acta, 70, 1188-214.

Begg G.C., Hronsky J.A.M., Arndt N.T., Griffin W.L., O'Reilly S.Y., Hayward N. 2010. Lithospheric, cratonic and geodynamic setting of Ni-Cu-PGE sulfide deposits. Economic Geology, 105, 1057-70.

Bekker A., Barley M.E., Fiorentini M.L., Rouxel O.J., Rumble D., Beresford S.W. 2009. Atmospheric sulfur in Archean komatiite-hosted nickel deposits. SCIENCE, 326, 1086-9.

Benko Z., Mogessie A., Molnar F., Severson M.J., Hauck S.A., Raic S. 2015. Partial melting processes and $\mathrm{Cu}-\mathrm{Ni}-\mathrm{PGE}$ mineralization in the footwall of the South Kawishiwi Intrusion at the Spruce Road deposit, Duluth Complex, Minnesota, USA. Economic Geology, in press.

Blewett R.S., Czarnota K., Henson P.A. 2010. Structural-event framework for the eastern Yilgarn Craton, Western Australia, and its implications for orogenic gold. Precambrian Research, 183, 203-29. 
Brugmann G.E., Naldrett A.J., Asif M., Lightfoot P.C., Gorbachev N.S., Fedorenko V.A. 1993. Siderophile and chalcophile metals as tracers of the evolution of the Siberian Trap in the Noril'sk region, Russia. Geochimica et Cosmochimica Acta, 57, 2001-18.

Bulle F., Layne G.D. 2015. Trace Element Variations in Olivine from the Eastern Deeps Intrusion at Voisey's Bay, Labrador, as a Monitor of Assimilation and Sulfide Saturation Processes Economic Geology, 110, 713-31: 10.2113/econgeo.110.3.713

Bunger A.P., Cruden A.R. 2011. Modeling the growth of laccoliths and large mafic sills; role of magma body forces. Journal of Geophysical Research, 116, 0-Citation B02203: http://dx.doi.org/10.1029/2010JB007648.

Campbell I.H. 2007. Testing the plume theory. Chemical Geology, 241, 153-76.

Campbell I.H., Barnes, Stephen J. 1984. A model for the geochemistry of the platinum group elements in magmatic sulphide deposits. Canadian Mineralogist, 22, 151-60.

Campbell I.H., Czamanske G.K., Fedorenko V.A., Hill R.I., Stepanov V. 1992. Synchromism of the Siberian Traps and the Permian-Triassic Boundary. SCIENCE, 258, 1760-3.

Campbell I.H., Griffiths R.W. 1990. Implications of mantle plume structure for the evolution of flood basalts. Earth and Planetary Science Letters, 99, 79-93.

Campbell I.H., Griffiths R.W., Hill R.I. 1989. Melting in an Archaean mantle plume: heads it's basalts, tails it's komatiites. Nature, 339, 697-9.

Campbell I.H., Naldrett A.J. 1979. The influence of silicate:sulphide ratios on the geochemistry of magmatic sulphides. Economic Geology, 74, 1503-6.

Cawthorn R. 2005. Contrasting sulphide contents of the Bushveld and Sudbury igneous complexes. Mineralium Deposita, 40, 1-12: 10.1007/s00126-005-0465-0.

Cawthorn R.G., Barnes, Stephen J., Ballhaus C., Malich K.N. 2005. Platinum group element, chromium and vanadium deposits in mafic and ultramafic rocks. Economic Geology, 100th Anniversary Volume, 215-49.

Chai G., Naldrett A.J. 1992. Characteristics of Ni-Cu-PGE mineralization and genesis of the Jinchuan deposit, northwest China. Economic Geology, 87, 1475-95.

Chung H.-Y., Mungall J.E. 2009. Physical constraints on the migration of immiscible fluids through partially molten silicates, with special reference to magmatic sulfide ores. Earth and Planetary Science Letters, 286, 14-22.

Cleverley J.S., Barnicoat A.C., Yardley B.W.D., Taylor G., Whitham A., Smith M., Griffiths J., Rivett M., Arthur J., Kendall M., Leat P., Thomas L., Peacock S., Catt J., Robinson R. 2007. 
Predictive mineral discovery; integrated research methods and new technologies used to generate mineral exploration targets: Geological Society of London, London.

Coffin M.F., Eldholm O. 1993. Scratching the surface; estimating dimensions of large igneous provinces. Geology (Boulder), 21, 515-8: http://dx.doi.org/10.1130/00917613(1993)021<0515:STSEDO>2.3.CO;2.

Courtillot V., Jaupart C., Manighetti I., Tapponnier P., Besse J. 1999. On causal links between flood basalts and continental breakup. Earth and Planetary Science Letters, 166, 177- 95.

Craig J.R., Kullerud G. 1969. Phase relations in the Cu-Fe-Ni-S system and their application to magmatic ore deposits. Economic Geology Monograph, 4, 344-58.

Cruden A.R. 1998. the emplacement of tabular granites. Journal of the Geological Society, London, $155,853-62$.

Cruden A.R. Emplacement and growth of plutons: implications for rates of melting and mass transfer in continental crust. In: Brown M, Rushmer T, editors. Evolution and Differentiation of the Continental Crust. Cambridge: Cambridge University Press; 2006. p. 455-519.

Cruden A.R., Burrows D., Evans-Lamswood D. Structure and emplacement of the Voisey's Bay troctolite and associated $\mathrm{Ni}-\mathrm{Cu}-\mathrm{Co}$ mineralization. GAC-MAC-SEG-SGA program with abstracts. Quebec City2008. p. 39.

Czamanske G.K., Zen'ko K.E., Fedorenko V., Calk L.C., Budahn J.R., Bullock J.H.J., Fries T.L., King B.S., Siems D.F. 1995. Petrographic and geochemical characterization of ore-bearing intrusions of the Noril'sk Type, Siberia; with discussion of their origin. Resource Geology Special Issue, 18, 1-48.

de Bremond d'Ars J., Arndt N.T., Hallot E. 2001. Analog experimental insights into the formation of magmatic sulfide deposits. Earth and Planetary Science Letters, 186, 371-81.

De Waal S.A., Xu Z.G., Li C.S., Mouri H. 2004. Emplacement of Viscous Mushes in the Jinchuan Ultramafic Intrusion, Western China. Canadian Mineralogist, 42, 371-92.

Ding X., Ripley E.M., Li C.S. 2012a. PGE geochemistry of the Eagle Ni-Cu-(PGE) deposit, Upper Michigan: constraints on ore genesis in a dynamic magma conduit. Mineralium Deposita, 47, 89-104.

Ding X., Ripley E.M., Shirey S.B., Li C. 2012e. Os, Nd, O and S isotope constraints on country rock contamination in the conduit-related Eagle Cu-Ni-(PGE) deposit, Midcontinent Rift System, upper Michigan. Geochimica et Cosmochimica Acta, 89, 10-30. 
Dobson D.P., Crichton W.A., Vocadlo L., Jones A.P., Wang Y., Uchida T., Rivers M., Sutton S., Brodholt J.P. 2000. In situ measurement of viscosity of liquids in the Fe-FeS system at high pressures and temperatures. AMERICAN MINERALOGIST, 85, 1838-42.

Dowling S.E., Barnes, Stephen J., Hill R.E.T., Hicks J. 2004. Komatiites and Nickel Sulfide Ores of the Black Swan area, Yilgarn Craton, Western Australia. 2. Geology and Genesis of the Orebodies. Mineralium Deposita, 39, 707-28.

Duuring P., Bleeker W., Beresford S.W. 2007. Structural modification of the komatiite-associated Harmony nickel sulfide deposit, Leinster, Western Australia. Economic Geology, 102, 27797.

Eilu P., Ahtola T., Aikas O., Halkoaho T., Heikura P., Hulkki H., Iljina M., Juopperi H., Karinen T., Karkkainen N., Konnunaho J., Kontinen A., Kontoniemi O., Korkiakoski E., Korsakova M., Kuivasaari T., Kylakoski M., Makkonen H., Niiranen T., Nikander J., Nykanen V., Perdahl J.-A., Pohjolainen E., Rasanen J., Sorjonen-Ward P., Tiainen M., Tontti M., Torppa A., Vasti K. 2012. Metallogenic areas in Finland. Special Paper - Geological Survey of Finland, 53, 207-342.

Elliot D.H., Fleming T.H. 2008. Physical volcanology and geological relationships of the Jurassic Ferrar large igneous province, Antarctica. Journal of Volcanology and Geothermal Research, 172, 20-37: http://dx.doi.org/10.1016/j.jvolgeores.2006.02.016.

Elliot D.H., Fleming T.H., Kyle P.R., Foland K.A. 1999. Long-distance transport of magmas in the Jurassic Ferrar large igneous province, Antarctica. Earth and Planetary Science Letters, 167, 89-104: http://dx.doi.org/10.1016/S0012-821X(99)00023-0.

Ernst R.E., Head J.W., Parfitt E., Grosfils E., Wilson L. 1995. Giant radiating dyke swarms on the Earth and Venus. Earth Science Reviews, 39, 1-58.

Evans-Lamswood D.M., Butt D.P., Jackson R.S., Lee D.V., Muggridge M.G., Wheeler R.I., Wilton D.H.C. 2000. Physical controls associated with the distribution of sulfides in the Voisey's Bay $\mathrm{Ni}-\mathrm{Cu}-\mathrm{Co}$ deposit, Labrador. Economic geology and the Bulletin Of the Society Of Economic Geologists, 95, 749.

Fedorenko V.A., Lightfoot P.C., Naldrett A.J., Czamanske G.K., Hawkesworth C.J., Wooden J.L., Ebel D.S. 1996. Petrogenesis of the flood-basalt sequence at Noril'sk, north central Siberia. International Geology Review, 38, 99-135.

Fiorentini M.L., Barnes, Stephen J., Lesher C.M., Heggie G.J., Keays R.R., Burnham O.M. 2010a. Platinum-group element geochemistry of mineralized and non-mineralized komatiites and basalts. Economic Geology, 105, 795-823. 
Fiorentini M.L., Beresford S.W., Rosengren N.M., Barley M.E., McCuaig T.C. 2010c. Contrasting komatiite belts, associated Ni-Cu-(PGE) deposit styles and assimilation histories. Australian Journal of Earth Sciences, 57, 543-66.

Galland O., Planke S., Neumann E.-R., Malthe-Sorensen A. 2009. Experimental modelling of shallow magma emplacement: Application to saucer-shaped intrusions. Earth and Planetary Science Letters, 277, 373-83.

Gao J.F., Zhou M.F., Lightfoot P.C., Wang C.Y., Qi L., Sun M. 2013. Sulfide-saturation and magma emplacement in the formation of the Permian Huangshandong Ni-Cu sulfide deposit, Xinjiang, NW China. Economic Geology, 108.

Gauert C.D.K., de Waal S.A., Wallmach T. 1995. Geology of the ultrabasic to basic Uitkomst Complex, eastern Transvaal, South Africa; an overview. JOURNAL OF AFRICAN EARTH SCIENCES, 21, 553-70.

Gauert C.D.K., Jordaan L.J., de Waal S.A., Wallmach T. 1996. Isotopic constraints on the source of sulphur for the base metal sulphides of the Uitkomst Complex, Badplaas, South Africa. South African Journal of Geology, 99, 41-50.

Godel B., Barnes, Stephen J., Barnes, Sarah-J. 2013. Deposition mechanisms of magmatic sulphide liquids: evidence from high-resolution X-ray computed tomography and trace element chemistry of komatiite-hosted disseminated sulphides. Journal of Petrology, 54, 1455-81: 10.1093/petrology/egt018.

Godel B., Seat Z., Maier W.D., Barnes, Sarah-J. 2011. The Nebo-Babel Ni-Cu-PGE sulfide deposit (West Musgrave Block, Australia); Pt. 2, Constraints on parental magma and processes, with implications for mineral exploration. Economic geology and the Bulletin Of the Society Of Economic Geologists, 106, 557.

Gole M.J., Robertson J., Barnes, Stephen J. 2013. Extrusive origin and structural modification of the komatiitic Mount Keith Ultramafic Unit. Economic Geology, 108, 1731-52: DOI: 10.2113/econgeo.108.7.1731.

Greeley R., Fagents S.A., Harris R.S., Kadel S.D., Williams D.A., Guest J.E. 1998. Erosion By Flowing Lava - Field Evidence. JOURNAL OF GEOPHYSICAL RESEARCH-SOLID EARTH, 103, 27325- 45.

Green A.H., Melezhik V.A. Geology of the Pechenga ore deposits - a review with comments on ore forming processes. In: Keays RR, Lesher CM, Lightfoot PC, Farrow CEG, editors. Dynamic Processes in Magmatic Ore Deposits and their Application in Mineral Exploration. Sudbury: Geological Association of Canada Short Course 13; 1999. p. 287-328. 
Griffin W., O'Reilly S.Y., Begg G.C. 2013. Continental-root control on the genesis of magmatic ore deposits. Nature GeoScience, 6, 905-10: 10.1038/NGEO1954.

Griffiths R.W., Campbell I.H. 1990. Stiring and structure in mantle starting plumes. Earth and Planetary Science Letters, 99, 66-78.

Grocott J., Arevalo C., Welkner D., Cruden A. 2009. Fault-assisted vertical pluton growth; Coastal Cordillera, north Chilean Andes. Journal of the Geological Society of London, 166, 295-301: http://dx.doi.org/10.1144/0016-76492007-165.

Grocott J., Taylor G.K. 2002. Magmatic arc fault systems, deformation partitioning and emplacement of granitic complexes in the Coastal Cordillera, north Chilean Andes (25 degrees 30'S to 27 degrees 00'S). Journal of the Geological Society of London, 159, Part 4, 425-42: http://dx.doi.org/10.1144/0016-764901-124.

Hansen D.M., Cartwright J. 2006. The three-dimensional geometry and growth of forced folds above saucer-shaped igneous sills. . JOURNAL OF STRUCTURAL GEOLOGY, 28, 1520-35.

Hanski E., Huhma H., Rastas P., Kamenetsky V.S. 2001. The Palaeoproterozoic komatiite-picrite association of Finnish lapland. Journal of Petrology, 42, 855- 76.

Hanski E.J. 1992. Petrology of the Pechenga ferropicrites and cogenetic Ni-bearing gabbro-wehrlite intrusions, Kola Peninsula, Russia. Geological Survey of Finland Bulletin, 367.

Haymon R.M., Fornari D.J., Edwards M.H., Carbotte S.M., Wright D., MacDonald K.C. 1991. Hydrothermal vent distribution along the East Pacific Rise crest ( 9 degrees 09 '-54' $\mathrm{N}$ ) and its relationship to magmatic and tectonic processes on fast-spreading mid-ocean ridges. Earth and Planetary Science Letters, 104, 513-34: http://dx.doi.org/10.1016/0012-821X(91)902268.

Heggie G.J., Fiorentini M.L., Barnes, Stephen J. 2013. Application of lithogeochemistry in the assessment of nickel-sulphide potential in komatiite belts from northern Finland and Norway. Bulletin of the Geological Society of Finland, 85, 107-26.

Herzberg C., Condie K., Korenaga J. 2010. Thermal history of the Earth and its petrological expression. Earth and Planetary Science Letters, 292, 79.

Herzberg C., Ohara M.J. 1998. Phase Equilibrium Constraints On the Origin Of Basalts, Picrites, and Komatiites. EARTH-SCIENCE REVIEWS, 44, 39- 79.

Holwell D.A., McDonald I. 2006. Petrology, geochemistry and the mechanisms determining the distribution of platinum group element and base metal sulfide mineralization in the Platreef at Overysel, northern Bushveld Complex, South Africa. Mineralium Deposita, 41, 575-98: http://dx.doi.org/10.1007/s00126-006-0083-5. 
Hon K., Kauahikaua J., Denlinger R., Mackay K. 1994. Emplacement and inflation of pahoehoe sheet flows: Observations and measurements of active lava flows on Kilauea Volcano, Hawaii. GEOLOGICAL SOCIETY OF AMERICA BULLETIN, 106, 351-70.

Huppert H.E., Sparks R.S.J. 1988a. The Generation of Granitic Magmas by Intrusion of Basalt into Continental Crust. Journal of Petrology, 29, 599-624.

Huppert H.E., Sparks R.S.J. 1988c. Melting the roof of a chamber containing a hot, turbulently convecting fluid. Journal of Fluid Mechanics, 188, 107-31.

Ireland T.J., Walker R.J., Garcia M.O. 2009. Highly siderophile element and Os-187 isotope systematics of Hawaiian picrites: Implications for parental melt composition and source heterogeneity. Chemical Geology, 260, 112-28.

Kamenetsky V.S., Maas R., Fonseca R.O.C., Ballhaus C., Heuser A., Brauns M., Norman M.D., Woodhead J.D., Rodemann T., Kuzmin D.V., Bonatti E. 2013. Noble metals potential of sulfide-saturated melts from the subcontinental lithosphere. Geology (Boulder), 41, 575-8: http://dx.doi.org/10.1130/G34066.1.

Kauahikaua J., Cashman K.V., Mattox T.N., Heliker C.C., Hon K.A., Mangan M.T., Thornber C.R. 1998. Observations On Basaltic Lava Streams In Tubes From Kilauea Volcano, Island Of Hawaii. JOURNAL OF GEOPHYSICAL RESEARCH-SOLID EARTH, 103, 27303- 23.

Kavanagh J.L., Menand T., Sparks R.S.J. 2006. An experimental investigation of sill formation and propagation in layered elastic media. Earth and Planetary Science Letters, 245, 799-813: http://dx.doi.org/10.1016/j.epsl.2006.03.025.

Keays R.R., Lightfoot, P.C. 2010. Crustal sulfur is required to form magmatic Ni-Cu sulfide deposits; evidence from chalcophile element signatures of Siberian and Deccan Trap basalts. Mineralium Deposita, 45, 241.

Keays, R.R., Lightfoot, P.C. 2015. Geochemical stratigraphy of the Keweenawan Midcontinent Rift volcanic rocks with regional implications for the genesis of associated $\mathrm{Ni}, \mathrm{Cu}, \mathrm{Co}$, and platinum group element sulfide mineralization. Economic Geology, in press.

Kerans C. 1983. Timing of emplacement of the Muskox Intrusion; constraints from Coppermine homocline cover strata. Canadian Journal of Earth Sciences $=$ Revue Canadienne des Sciences de la Terre, 20, 673-83: http://dx.doi.org/10.1139/e83-061.

Krivolutskaya N.A. 2014. Evolution of trap magmatism and processes producing Pt-Cu-Ni mineralization in the Noril'sk area (in Russian). Moscow: KMK.

Layton-Matthews D., Lesher C.M., Burnham O.M., Liwanag J., Halden N.M., Hulbert L., Peck D.C. Magmatic Ni-Cu-platinum-group element deposits of the Thompson Nickel Belt. In: 
Goodfellow WD, editor. Mineral Deposits of Canada: A Synthesis of Major Deposit-Types, District Metallogeny, the Evolution of Geological Provinces, and Exploration Methods Geological Associaton of Canada Special Publication 5. Ottawa: Geological Associaton of Canada, Mineral Deposits Division; 2007. p. 409-32.

Le Vaillant M., Barnes, Stephen J., Fiorentini M.L., Miller J.M., McCuaig T.C., Mucilli P. 2015. A hydrothermal Ni-As-PGE geochemical halo around the Miitel komatiite-hosted nickel sulfide deposit, Yilgarn Craton, Western Australia. Economic Geology, 110, 505-30: 03610128/15/0000/1-22.

Leaman D.E. 1975. Form, mechanism, and control of dolerite intrusion near Hobart, Tasmania. Journal of the Geological Society of Australia, 22, Part 2, 175-86.

Lehmann J., Arndt N., Windley B., Zhou M.F., Wang C.Y., Harris C. 2007. Field Relationships and Geochemical Constraints on the Emplacement of the Jinchuan Intrusion and Its Ni-Cu-Pge Sulfide Deposit, Gansu, China. Economic Geology, 102, 75-94.

Leitch A.M. 2004. Analog experiments on melting and contamination at the roof and walls of magma chambers. Journal of Volcanology and Geothermal Research, 129, 173-97: http://dx.doi.org/10.1016/S0377-0273(03)00239-7.

Lesher C.M. Komatiite-associated nickel sulfide deposits. In: Whitney JA, Naldrett AJ, editors. Ore Deposition Associated with Magmas. El Paso: Economic Geology Publishing Company; 1989. p. 44-101.

Lesher C.M. Deposits in the Raglan Area, Cape Smith Belt, New Québec. In: Goodfellow WD, editor. Mineral Deposits of Canada: A Synthesis of Major Deposit-Types, District Metallogeny, the Evolution of Geological Provinces, and Exploration Methods Geological Associaton of Canada Special Publication 5. Ottawa: Geological Associaton of Canada, Mineral Deposits Division; 2007. p. 351-86.

Lesher C.M., Arndt N.T., Groves D.I. Genesis of komatiite-associated nickel sulphide deposits at Kambalda Western Australia: a distal volcanic model. In: Buchanan DL, Jones MJ, editors. Sulphide Deposits in Mafic and Ultramafic Rocks. London: Institute of Mining and Metallurgy; 1984. p. 70-80.

Lesher C.M., Burnham O.M. 2001. Multicomponent elemental and isotopic mixing in Ni-Cu-(PGE) ores at Kambalda, Western Australia. Canadian Mineralogist, 39, 421- 46.

Lesher C.M., Burnham O.M., Keays R.R., Barnes, Stephen J., Hulbert L. 2001. Trace-element geochemistry and petrogenesis of barren and ore-associated komatiites. Canadian Mineralogist, 39, 673- 96. 
Li C., Barnes, Sarah-J., Makovicky E., Rose-Hansen J., Makovicky M. 1996. Partitioning of Ni, Cu, Ir, Rh, Pt and Pd between monosulfide solid solution and sulfide liquid: Effects of composition and temperature. Geochimica Cosmochimica Acta, 60, 1231-8.

Li C., Naldrett. 2000. Melting reactions of gneissic inclusions with enclosing magma at Voisey's Bay, Labrador, Canada; implications with respect to ore genesis. Economic geology and the Bulletin Of the Society Of Economic Geologists, 95, 801-14.

Li C., Naldrett A.J. 1999. Geology and petrology of the Voisey's Bay intrusion: reaction of olivine with sulfide and silicate liquids. Lithos, 47, 1- 31.

Li C., Ripley E.M., Naldrett A.J. 2009. A new genetic model for the giant Ni-Cu-PGE sulfide deposits associated with the Siberian flood basalts. Economic geology and the Bulletin Of the Society Of Economic Geologists, 104, 291-301.

Li C.S., Zhang M.J., Fu P., Qian Z.Z., Hu P.Q., Ripley E.M. 2012. The Kalatongke magmatic Ni-Cu deposits in the Central Asian Orogenic Belt, NW China: product of slab window magmatism? Mineralium Deposita, 47, 51-67.

Lightfoot P.C., Evans-Lamswood D.M. 2015. Structural controls on the primary distribution of mafic-ultramafic intrusions containing $\mathrm{Ni}-\mathrm{Cu}-\mathrm{Co}-(\mathrm{PGE})$ sulfide mineralization in the roots of large igneous provinces. Ore Geology Reviews, 64, 354-86.

Lightfoot P.C., Farrow C.E.G. 2002. Geology, geochemistry, and mineralogy of the Worthington offset dike: A genetic model for offset dike mineralization in the Sudbury Igneous Complex. Economic geology and the Bulletin Of the Society Of Economic Geologists, 97, 1419- 46.

Lightfoot P.C., Keays R.R. 2005. Siderophile and Chalcophile Metal Variations in Flood Basalts from the Siberian Trap, Noril'sk Region: Implications for the Origin of the Ni-Cu-PGE Sulfide Ores. Economic Geology, 100, 439-62.

Lightfoot P.C., Keays R.R., Evans-Lamswood D., Wheeler R. 2012. S saturation history of Nain plutonic suite mafic intrusions; origin of the Voisey's Bay Ni-Cu-Co sulfide deposit, Labrador, Canada. Mineralium Deposita, 47, 23-50.

Lightfoot P.C., Keays R.R., Morrison G.G., Bite A., Farrell K.P. 1997a. Geochemical raltionships in the Sudbury Igneous Complex - origin of the Main Mass and Offset Dykes. Economic Geology, 92, 289-307.

Lightfoot P.C., Keays R.R., Morrison G.G., Bite A., Farrell K.P. 1997b. Geologic and Geochemical Relationships Between the Contact Sublayer, Inclusions, and the Main Mass Of the Sudbury Igneous Complex - a Case Study Of the Whistle Mine Embayment. Economic geology and the Bulletin Of the Society Of Economic Geologists, 92, 647- 73. 
Lightfoot P.C., Zotov I.A. 2005. Geology and Geochemistry of the Sudbury Igneous Complex, Ontario, Canada: Origin of Nickel Sulfide Mineralization Associated With an ImpactGenerated Melt Sheet. Geology of Ore Deposits, 47, 349-81.

Lightfoot P.C., Zotov I.A. 2014. Geological relationships between the intrusions, country rocks and $\mathrm{Ni}-\mathrm{Cu}-\mathrm{PGE}$ sulfides of the Kharealakh Intrusion, Noril'sk region: Implications for the role of sulfide differentiation and metasomatism in their genesis. Northwestern Geology, 47, 1-35.

Lister J.R., Kerr R.C. 1991. Fluid-mechanical models of crack propagation and their application to magma transport in dykes. Journal of Geophysical Research, 96-B6, 10049-77: http://dx.doi.org/10.1029/91JB00600.

Maier W.D., Gomwe T., Barnes, Stephen J., Li C., Theart H. 2004. Platinum Group Elements in the Uitkomst Complex, South Africa. Economic Geology, 99, 499-516.

Mangan M.T., Heliker C.C., Mattox T.N., Kauahikaua J.P., Helz R.T. 1995. Episode 49 of the Pu'u 'O'o-Kupaianaha eruption of Kilauea volcano-breakdown of a steady-state eruptive area. Bulletin pf Volcanology, 57, 127-35.

Marsh B.D. 2004. A magmatic mush column rosetta stone: The McMurdo Dry Valleys of Antarctica. Eos, Transactions American Geophysical Union, 85, 497-502.

Mavrogenes J.A., O'Neill H.S.C. 1999. The relative effects of pressure, temperature and oxygen fugacity on the solubility of sulfide in mafic magmas. Geochimica et Cosmochimica Acta, 63, 1173- 80.

McBirney A.R., Murase T. 1984. Rheological properties of magmas. Annual Review Of Earth and Planetary Sciences, 12, 337-57.

McCuaig T.C., Hronsky J.M.A. 2000. The current status and future of the interface between the exploration industry and economic geology research. Reviews in Economic Geology, 13, 553-9.

McCuaig T.C., Hronsky J.M.A. 2014. The Mineral System concept: the key to exploration targeting. Society of Economic Geologists Special Publication, 18, 153-75.

McDonald I., Holwell D.A. 2007. Did lower zone magma conduits store PGE-rich sulphides that were later supplied to the Platreef? South African Journal of Geology, 110, 611-6: http://dx.doi.org/10.2113/gssajg.110.4.611.

McQueen K.G. 1979. Experimental heating and diffusion effects in Fe-Ni sulphide ore from Redross, Western Australia. Economic Geology, 74, 140-8.

McQueen K.G. 1987. Deformation and remobilization in some Western Australian nickel ores. Ore Geology Reviews, 2, 269-86. 
Medard E., Grove T.L. 2005. Influence of $\mathrm{H} 2 \mathrm{O}$ on liquidus temperature of primitive basalts and olivine-liquid thermometry. AGU Fall Meeting Abstract V41E, 1517.

Menand T. 2008. The mechanics and dynamics of sills in layered elastic rocks and their implications for the growth of laccoliths and other igneous complexes. Earth and Planetary Science Letters, 267, 93-9: http://dx.doi.org/10.1016/j.eps1.2007.11.043.

Menzies M., Baker J., Bosence D., Dart C., Davison I., Hurford A., Al-Kadasi M., McKlay K., Nichols G., Al-Subbary A., Yelland A. The timing of magmatism, uplift and crustal extension: preliminary observations from Yemen. In: Storey BC, Alabaster T, Pankhurst RJ, editors. Magmatism and the Causes of Continental Breakup. London: Geological Society; 1992. p. 293-304.

Miles A.J., Cartwright J.A. 2010. Hybrid flow sills: a new mode of igneous sheet intrusion. Geology, 38, 343-6.

Miller J.D., Jr., Vervoort J.D., Woodruff L.G., Nicholson S.W. 1996. The latent magmatic stage of the Midcontinent Rift; a period of magmatic underplating and melting of the lower crust. Proceedings and Abstracts - Institute on Lake Superior Geology Meeting, 42, Part 1, 33-5.

Mole D., Fiorentini M.L., Thebaud N., Cassidy K.F., McCuaig T.C., Kirkland C.L., Romano S., Doublier M.P., Belousova E., Barnes, Stephen J., Miller J.M. 2014. Archean komatiite volcanism controlled by the evolution of early continents. . Proceedings of the National Academy Of Sciences, 111, 10083-8: 10.1073/pnas.1400273111.

Mota-e-Silva J., Ferreira Filho C.F., Della Giustina M.E.S. 2013. The Limoeiro Deposit: Ni-Cu-PGE Sulfide Mineralization Hosted Within an Ultramafic Tubular Magma Conduit in the Borborema Province, Northeastern Brazil Economic Geology, 108, 1753-71: doi:10.2113/econgeo.108.7.1753.

Mungall J.E. 2002. Kinetic controls on the partitioning of trace elements between silicate and sulfide liquids. Journal of Petrology, 43, 749- 68.

Mungall J.E. 2007a. Crustal Contamination of Picritic Magmas During Transport Through Dikes: the Expo Intrusive Suite, Cape Smith Fold Belt, New Quebec. Journal of Petrology, 48, 1021-39.

Mungall J.E. 2007b. Crystallization of magmatic sulfides; an empirical model and application to Sudbury ores. Geochimica et Cosmochimica Acta, 71, 2809.

Mungall J.E. Magmatic Ore Deposits. 2007c. In: Holland HD, Turekian KK, editors. Treatise on Geochemistry: (First edition). Elsevier; 2007c.

Mungall J.E., 2014, Geochemistry of Magmatic Ore Deposits. In: Holland HD, Turekian KK, editors. Treatise on Geochemistry (Second Edition). Ocford: Elsevier. p. 195-218. 
Mungall J.E., Brenan J.M. 2014. Partitioning of platinum-group elements and Au between sulfide liquid and basalt and the origins of mantle-crust fractionation of the chalcophile elements. Geochimica et Cosmichimica Acta, 125, 265-89: 10.1016/j.gca.2013.10.002.

Mutanen T., Huhma H. U-Pb geochronology of the Koitelainen, Akanvaara and Keivitsa mafic layered intrusions and related rocks. In: Vaasjoki M, editor. Radiometric age determinations from Finnish Lapland and their bearing on the timing of Precambrian volcano-sedimentary sequences Geological Survey of Finland Special Paper 33. Helsinki: Geological Survey of Finland; 2001. p. 229-46.

Myers J.S., Voordouw R.J., Tettelaar T.A. 2008. Proterozoic anorthosite-granite Nain Batholith; structure and intrusion processes in an active lithosphere-scale fault zone, northern Labrador. Canadian Journal of Earth Sciences = Revue Canadienne des Sciences de la Terre, 45, 90934: http://dx.doi.org/10.1139/E08-041.

Naldrett A.J. 2011. Fundamentals of Magmatic Sulfide Deposits. Reviews in Economic Geology, 17, $1-50$.

Naldrett A.J. 1973. Nickel sulphide deposits: their classification and genesis, with special emphasis on deposits of volcanic association. Canadian Institute of Mining and Metallurgy Bulletin, 66, 45-63.

Naldrett A.J. 1981. Nickel sulphide deposits: classification, composition and genesis. Economic Geology, 75th Anniversary Volume, 628-87.

Naldrett A.J. 1989. Ores associated with flood basalts. In: Whitney JA, Naldrett AJ, editors. El Paso: Society of Economic Geologists. p. 103-34.

Naldrett A.J. 1992. A model for the Ni-Cu-PGE ores of the Noril'sk region and its application to other areas of flood basalt. Economic Geology, 87, 1945-62.

Naldrett A.J. 1997. Key Factors In The Genesis Of Norilsk, Sudbury, Jinchuan, Voiseys Bay And Other World-Class Ni-Cu-Pge Deposits - Implications For Exploration. Australian Journal of Earth Sciences, 44, 283-315.

Naldrett A.J. 1999a. Summary; Development of ideas on Sudbury geology, 1992-1998. Special papers (Geological Society of America), 339, 431.

Naldrett A.J. 1999b. World-class Ni-Cu-PGE deposits: key factors in their genesis. Mineralium Deposita, 34, 227- 40.

Naldrett A.J. 2004. Magmatic Sulfide Deposits: Geology, Geochemistry and Exploration. Heidelberg: Springer. 
Naldrett A.J. 2005. A History of Our Understanding of Magmatic Ni-Cu Sulfide Deposits. Canadian Mineralogist, 43, 2069-98.

Naldrett A.J. 2010a. From the mantle to the bank: The life of a Ni-Cu-(PGE) sulfide deposit. South African Journal of Geology, 113, 1-32.

Naldrett A.J. 2010b. Secular variation of magmatic sulfide deposits and their source magmas. Economic Geology, 105, 669-88.

Naldrett A.J., Fedorenko V.A., Asif M., Lin S., Kunilov V.E., Stekhin A.I., Lightfoot P.C., Gorbachev N.S. 1996. Controls on the composition of Ni-Cu sulfide deposits as illustrated by those at Noril'sk, Siberia. Economic geology and the Bulletin Of the Society Of Economic Geologists, 91, 751-73: http://dx.doi.org/10.2113/gsecongeo.91.4.751.

Naldrett A.J., Innes D.G., Sowa J., Gorton M.P. 1982. Compositonal variations within and between five Sudbury ore deposits. Economic Geology, 77, 1519-34.

Naldrett A.J., Lightfoot P.C. 1999. Ni-Cu-PGE deposits of the Noril'sk region, Siberia: their formation in conduits for flood basalt volcanism. In: R.R. Keays RR, C.M. Lesher CM, P.C. Lightfoot PC, Farrow CEG, editors. Sudbury: Geological Association of Canada Short Course 13. p. $195-249$.

Naldrett A.J., Lightfoot P.C., Fedorenko V., Doherty W., Gorbachev N.S. 1992. Geology and geochemistry of intrusions and flood basalts of the Noril'sk region, USSR, with implications for the origin of the Ni-Cu ores. Economic Geology, 87, 975-1004.

Ortega L., Lunar R., Garcia-Palomero F., Moreno T., Martin-Estrevez J.R., Prichard H.M., Fisher P.C. 2004. The Aguablanca Ni-Cu-Pge Deposit, Southwestern Iberia: Magmatic Ore-Forming Processes and Retrograde Evolution. Canadian Mineralogist, 42, 325-50.

Peltonen P. 1995. Petrogenesis of ultramafic rocks in the Vammala Nickel Belt: implications for crustal evolution of the early Proterozoic Svecofennian arc terrain. Lithos, 34, 253-74.

Pina R., Lunar R., Ortega L., Gervilla F., Alapieti T., Martinez C. 2006. Petrology and Geochemistry of Mafic-Ultramafic Fragments From the Aguablanca Ni-Cu Ore Breccia, Southwest Spain. Economic Geology, 101, 865-81.

Planke S., Rasmussen T., Rey S.S., Myklebust R. 2005. Seismic characteristics and distribution of volcanic intrusions and hydrothermal vent complexes in the Voring and More basins. Petroleum Geology of Northwest Europe: Proceedings of the Conference, 6, 833-44.

Pollard D.D., Muller O.H., Dockstader D.R. 1975. The form and growth of fingered sheet intrusions. Geological Society of America Bulletin , 86, 351-63. 
Polteau S., Mazzini A., Galland O., Planke S., Malthe-Sorenssen A. 2008. Saucer-shaped intrusions; occurrences, emplacement and implications. Earth and Planetary Science Letters, 266, 195204: http://dx.doi.org/10.1016/j.eps1.2007.11.015.

Rajamani V., Naldrett A.J. 1978. Partitioning of $\mathrm{Fe}, \mathrm{Co}$, Ni and $\mathrm{Cu}$ between sulfide liquid and basaltic melts and the composition of Ni-Cu sulfide deposits. Economic Geology, 73, 82-93.

Richards M.A., Duncan R.A., Courtillot V.E. 1989. Flood basalts and hotspot tracks; plume heads and tails. Science, 246, 103-6.

Ripley E.M. 2014. Ni-Cu-PGE mineralization in the Partridge River, South Kawishiwi, and Eagle Intrusions; a review of contrasting styles of sulfide-rich occurrences in the Midcontinent Rift System. Economic geology and the Bulletin Of the Society Of Economic Geologists, 109, 309-24: http://dx.doi.org/10.2113/econgeo.109.2.309.

Ripley E.M., Li C.S. 2013. Sulfide saturation in mafic magmas; is external sulfur required for magmatic Ni-Cu-(PGE) ore genesis? Economic geology and the Bulletin Of the Society Of Economic Geologists, 108, 45-58: http://dx.doi.org/10.2113/econgeo.108.1.45.

Ripley E.M., Li C.S. 2003. Sulfur isotope exchange and metal enrichment in the formation of magmatic Cu-Ni-(PGE) deposits. Economic geology and the Bulletin Of the Society Of Economic Geologists, 98, 635- 41.

Ripley E.M., Lightfoot P.C., Li C., Elswick E.R. 2003. Sulfur isotopic studies of continental flood basalts in the Noril'sk region: Implications for the association between lavas and ore-bearing intrusions. Geochimica et Cosmochimica Acta, 67, 2805- 17.

Ripley E.M., Lightfoot P.C., Stifter E.C., Underwood B., Taranovic V., Dunlop M., Donoghue K.A. 2015. Heterogeneity of S isotope compositions recorded in the Sudbury Igneous Complex, Canada: significance to formation of Ni-Cu sulfide ores and the host rocks. Economic Geology, 110, 1125-35: 10.2113/econgeo.110.4.1125.

Robertson J.C., Barnes, Stephen J., Le Vaillant M. 2015a. Dynamics of magmatic sulphide droplets during transport in silicate melts and implications for magmatic sulphide ore formation. Journal of Petrology, accepted with revisions.

Robertson J.C., Barnes, Stephen J., Metcalfe G. Chaotic entrainment can drive sulfide remobilization at low magma flow rates. 13th International Platinum Symposium. Yekaterinburg, Russia: Russian Academy of Sciences, Ural Branch; 2014. p. 47-8.

Robertson J.C., Ripley E.M., Barnes, Stephen J., Li C. 2015e. Sulfur Liberation from Country Rocks and Incorporation in Mafic Magmas. Economic Geology, in revision. 
Rubin A.M. 1995. Propagation of magma-filled cracks. Annual Review in Earth and Planetary Sciences, 23, 287-336.

Rubin A.M., Pollard D.D. 1987. Origins of blade-like dikes in volcanic rift zones. U S Geological Survey Professional Paper, 1449-70.

Ryan B. 2001. A provisional subdivision of the Nain plutonic suite in its type-area, Nain, Labrador (NTS map area 14C/12). Report - Government of Newfoundland and Labrador Dept of Mines and Energy, Geological Survey, 127-57.

Saumur B.M., Cruden A.R. 2015. On the emplacement of the Voisey's Bay intrusion (Labrador, Canada). GEOLOGICAL SOCIETY OF AMERICA BULLETIN, in press.

Saumur B.M., Cruden A.R., Boutelier D., Evans-Lamswood D.M. Structure and dynamics of magmatic Ni-Cu sulphide deposits: theory, analogue modelling and insights from Voisey's Bay (Labrador, Canada). . 13th biennial SGA meeting. Uppsala, Sweden: SGA; 2013.

Saumur B.M., Cruden A.R., Evans-Lamswood D.M., Lightfoot P.C. 2015. Wall-Rock Structural Controls on the Genesis of the Voisey's Bay Intrusion and its Ni-Cu-Co Magmatic Sulfide Mineralization (Labrador, Canada). Economic Geology, in press.

Saunders A.D., Fitton J.G., Kerr A.C., Norry M.J., Kent R.W. The North Atlantic Igneous Province. In: Mahoney JJ, Coffin MF, editors. Large igneous provinces: continental, oceanic and planetary flood volcanism. Washington: American Geophysical Union; 1997. p. 95-122.

Schofield N.J., Brown D.J., Magee C., Stevenson C.T. 2012. Sill morphology and comparison of brittle and non-brittle emplacement mechanisms. Journal of the Geological Society of London, 169, 127-41: http://dx.doi.org/10.1144/0016-76492011-078.

Seat Z., Beresford S.W., Grguric B.A., Waugh R.S., Hronsky J.M.A., Gee M.A.M., Groves D.I., Mathison C.I. 2007. Architecture and emplacement of the Nebo-Babel gabbroborite-hosted magmatic Ni-Cu-PGE sulphide deposit, West Musgrave, Western Australia. Mineralium Deposita, 42, 551-81.

Seat Z., Gee M.A.M., Grguric B.A., Beresford S.W., Grassineau N.V. 2011. The Nebo-Babel Ni-CuPGE sulfide deposit (West Musgrave, Australia); Part 1; U/Pb zircon ages, whole-rock and mineral chemistry, and O-Sr-Nd isotope compositions of the intrusion, with constraints on petrogenesis. Economic geology and the Bulletin Of the Society Of Economic Geologists, 106, 527-56: http://dx.doi.org/10.2113/econgeo.106.4.527.

Sinigoi S., Quick J.E., Clemens-Knott D., Mayer A., Demarchi G., Mazzucchelli M., Negrini L., Rivalenti G. 1994. Chemical evolution of a large mafic intrusion in the lower crust, Ivrea- 
Verbano Zone, northern Italy. Journal of Geophysical Research, 99, 21-,590: http://dx.doi.org/10.1029/94JB00114.

Skufin P.K., Theart H.F.J. 2005. Geochemical and tectono-magmatic evolution of the volcanosedimantary rocks of pechenga and other greenstone fragments within the Kola Greenstone Belt, Russia. Precambrian Research, 141, 1-48.

Sleep N.H., Ebinger C.J., Kendall J.M. 2002. Deflection of mantle plume material by cratonic keels. Geological Society Special Publication, 199, 135-50.

Sluzhenikin S.F., Krivolutskaya N.A., Rad'ko V., Malitch K.N., Distler V.V., Fedorenko V.A. 2014. Ultramafic-mafic intrusions, volcanic rocks and PGE-Cu-Ni sulfide deposits of the Noril'sk Province, Polar Siberia, Field Trip Guidebook. Yekaterinburg, Russia.: Institute of Geology of Ore Deposits, Petrography, Mineralogy and Geochemistry.

Smithies R.H., Howard H.M., Evins P.M., Kirkland C.L., Kelsey D.E., Hand M., Wingate M.T.D., Collins A.S., Belousova E. 2011. High-temperature granite magmatism, crust-mantle interaction and the Mesoproterozoic intracontinental evolution of the Musgrave Province, central Australia. Journal of Petrology, 52, 931-58: http://dx.doi.org/10.1093/petrology/egr010.

Sobolev A., Hoffman A., Kuzmin D., Yaxley G., Arndt N., Chung S.-L., Danyushevsky L., Elliott T., Frey F., Garcia M., Gurenko A., Kamenetsky V., Kerr A., Krivolutskaya N., Matvienkov V., Nikogosian I., Rocholl A., Sigurdson I., Sushchevskaya N., Teklay M. 2007. The amount of recycled crust in sources of mantle-derived melts. SCIENCE, 316, 412-7.

Sobolev A.V., Hofmann A.W., Sobolev S.V., Nikogosian I.K. 2005. An olivine-free mantle source of Hawaiian shield basalts. Nature (London), 434, 590.

Sobolev S.V., Sobolev A.V., D.V. K., Krivolutskaya N.A., Petrunin A.G., Arndt N.T., Radko V.A., Y.R V. 2011. Linking mantle plumes, large igneous provinces and environmental catastrophes. Nature, 477, 312-8.

Song X., Xie W., Deng Y., Crawford A.J., Zheng W., Zhou G., Deng G., Cheng S., Li J. 2011. Slab break-off and the formation of Permian mafic-ultramafic intrusions in southern margin of Central Asian orogenic belt, Xinjiang, NW China. Lithos (Oslo), 127, 128-43: http://dx.doi.org/10.1016/j.lithos.2011.08.011.

Song X.Y., Danyushevsky L.V., Keays R.R., Chen L.-M., Wang Y.-S. 2012. Structural, lithological, and geochemical constraints on the dynamic magma plumbing system of the Jinchuan $\mathrm{Ni}-\mathrm{Cu}$ sulfide deposit, NW China. Mineralium Deposita, 47, 277-97. 
Tang Z. 1991. The metallogenetic model of the Jinchuan platinum-bearing copper-nickel sulphide deposit. International Symposium on Sulfide Deposits, Academic Papers on Special Subjects, Jinchang, Gansu, China, 17-43.

Taranovic V., Ripley E.M., Li C., Rossell D. 2015. Petrogenesis of the Ni-Cu-PGE sulfide-bearing Tamarack Intrusive Complex, Midcontinent Rift System, Minnesota. Lithos, 212-215, 16-31.

Tarduno J.A., Duncan R.A., Scholl D.W., Cottrell R.D., Steinberger B., Thordarson T., Kerr B.C., Neal C.R., Frey F.A., Torii M., Carvallo C. 2003. The Emperor Seamounts: Southward Motion of the Hawaiian Hotspot Plume in Earth's Mantle. SCIENCE, 301, 1064-9: 10.1126/science. 1086442 .

Thompson J.F.H., Naldrett A.J. 1984. Sulphide-silicate reactions as a guide to Ni-Cu-Co mineralization in central Maine, U.S.A: Inst. Min. and Metall., London.

Tonnelier N., Lesher C.M., Arndt N.T. Petrology and geochemistry of the Jinchuan intrusion and asssociated Ni-Cu-(PGE) mineralization, Xi'an Ni-Cu Symposium, Xi'an, China. Xi'an NiCu Symposium. Xi'an (China)2009.

Weibe R.A., Collins W.J. 1998. Depositional features and stratigraphic sections in granitic plutons: implications for the emplacement and crystallization of granitic magma. Journal of Sturctural Geology, 20, 1273-89.

Wooden J.L., Czamanske G.K., Bouse R.M., Likhachev A.P., Kunilov V.E., Lyul'ko V. 1992. Pb isotope data indicate a complex, mantle origin for the Noril'sk-Talnakh ores, Siberia. Economic Geology, 87, 1153-65.

Wooden J.L., Czamanske G.K., Fedorenko V.A., Arndt N.T., Chauvel C., Bouse R.M., King B.W., Knight R.J., Siems D.F. 1993. Isotopic and trace-element constraints on mantle and crustal contributions to Siberian continental flood basalts, Noril'sk area, Siberia. Geochimica et Cosmochimica Acta, 57, 3677-704.

Wyborn L.A.I., Heinrich C.A., Jaques A.L. 1994. Australian Proterozoic mineral systems; essential ingredients and mappable criteria. Publication Series - Australasian Institute of Mining and Metallurgy, 5/94, 109-15.

Xia M.Z., Jiang C.Y., Li C., Xia Z.D. 2013. Constraints on the Origin of the Huangshandong Magmatic Ni-Cu Sulfide Deposit in the Central Asian Orogenic Belt, NW China. Economic Geology, 108.

Yakubchuk A., Nikishin A. 2004. Noril'sk-Talnakh Cu-Ni-PGE deposits; a revised tectonic model. Mineralium Deposita, 39, 125-42: http://dx.doi.org/10.1007/s00126-003-0373-0. 
Yang S.-H., Maier W.D., Hanski E.J., Lappalainen M., Santaguida F., Maatta S. 2013. Origin of ultranickeliferous olivine in the Kevitsa Ni-Cu-PGE-mineralized intrusion, northern Finland. Contributions to Mineralogy and Petrology, 166, 81-95: http://dx.doi.org/10.1007/s00410013-0866-5.

Zen'ko T.E., Czamanske G.K. Spatial and petrologic aspects of the intrusions of the Noril'sk and Talnakh ore junctions. In: Lightfoot PC, Naldrett AJ, editors. Toronto: Ontario Geological Survey; 1992. p. 263-81.

Zhang M., O'Reilly S., Wang K.-L., Hronsky J., Griffin W. 2008. Flood basalts and metallogeny: the lithosphere mantle connection. Earth Science Reviews, 86, 145-74.

Zhou M.-F., Yang Z.-X., Song X.-Y., Keays R.R., Lesher C.M. Magmatic Ni-Cu-(PGE) sulphide deposits in China. . In: Cabri LJ, editor. The Geology, Geochemistry, Mineralogy and Mineral Beneficiation of Platinum-Group Elements. Ottawa: Canadian Institute of Mining, Metallurgy and Petroleum; 2002. p. 619-36.

Zhou M.-F., Arndt N.T., Malpas J., Wang C.Y., Kennedy A.K. 2008. Two magma series and associated ore deposit types in the Permian Emeishan large igneous province, SW China. Lithos, 103, 352-68: http://dx.doi.org/10.1016/j.lithos.2007.10.006.

Figure captions

Figure 1. (A) Starting plume ascending beneath an Archaean craton, within a few hundred kilometers of an original craton boundary. Plume head is mixture of high temperature tail) and entrained ambient mantle (Campbell et al., 1989; Griffiths and Campbell, 1990). (B ) Impingement and flattening of plume head beneath lithosphere. (C) Channelling of plume head and tail to thinnest lithosphere at craton margin, generation of continental rifting cantered on original suture, and onset of high-Mg, low-Ti melts production. Maximum melt production occurs beneath the craton margin, controlled by flow of plume along sloping base of cratonic lithosphere (Begg et al., 2010), focusing of predominant flux of komatiite plume-tail melt at craton margin. (D) Development of favorable and unfavorable environments for mineralisation above the melting zone, showing the combination of long-lived mantle-tapping structure and high magma production giving rise to high flux "magma freeways" with potential for assimilation of crustal S, transport and deposition of magmatic sulphide ores.

Figure 2. Compositions of mantle-derived lavas from continental large igneous provinces and oceanic plume settings, showing estimated range of parent magma compositions for various styles of 
magmatic Ni-Cu-PGE deposits. Data from compilation by Fiorentini et al. (2010a). RKB = Raglan komatiitic basalts, Mk, NMS = Morongovsky Formation (Siberian Traps, Noril’sk))

Figure 3. Densities of magma-olivine-sulphide suspensions in basaltic melts.

Figure 4. Model for structurally-controlled emplacement as exemplified by the Discovery Hill Dyke at Voisey's Bay (a) vertical cross section of a dyke that has propagated through a pre-existing fracture network. The ideal orientation of the dyke is vertical but it is locally reoriented into parallelism with fractures and foliation planes. (b) thermo-mechanical erosion of dyke walls leads to preferential widening of gently dipping sections. See text for discussion. (c) Sketch cross section of intrusive phases and mineralisation within the Discovery Hill Dyke, Voisey's Bay. (d) 3D sketch of part of a funnel-shaped jog within the Discovery Hill Dyke, Voisey's Bay showing relationships between the dykes, pre-existing fractures and foliation planes in the country rock. The fault post dates the intrusion. (a - c modified from Saumur et al 2015, in press).

Figure 5. Schematic illustration of the spectrum of characteristic geometries of composite mafic and mafic-ultramafic intrusions known to host magmatic Ni-Cu-PGE sulphide mineralisation. A. Noril'sk type from Naldrett (2004). B. Chonolith type based on Nebo-Babel (accepting the interpretation that this deposit and host intrusion is structurally overturned) and Limoeira (Seat et al., 2007, Mota-eSilva et al., 2013). C,D. Eagle - Kalatongke type based on interpreted geometries of these two intrusions, and other elongate dyke-keel complexes in China including Huangshangdong, Limahe and Jingbulake, from various authors (Zhou et al., 2002, Song et al., 2011, Ding et al., 2012a, Lightfoot and Evans-Lamswood, 2015). E. Blade-shaped dyke type based on Savannah (formerly Sally Malay, Western Australia, unpublished) and Mesamax and other intrusions of the South Raglan tend, northern Quebec (Mungall, 2007).

Figure 6. Examples of breakdown of propagating sills into steps (a), lobes (b) and ribbon-like geometries (c), all modified from Schofield (2012). (a) A sill propagating from left to right steps and breaks down into segments, which then bridge and join. (b) Interpretation map of a 3D seismic survey showing occurrence of magma lobes with breakout structures within a shallow level sill (redrawn from Hansen \& Cartwright, 2006). (c) Interpretation map of a 3D seismic survey showing a shallowlevel channel like sill feeding magma lobes with ragged edges (redrawn from Miles \& Cartwright (2010).

Figure 7. Examples of downward injection of sulphide melts into footwall rocks in a variety of deposit types. A,B. Sulphide melt injecting dacite at the Silver Swan komatiite-hosted deposit, Western Australia (sulphide in red, dacite footwall unit in grey in (b). Sulphide liquid fills fractures in dacite, dacite inclusions in sulphide are a connected framework of partially molten buoyantly ascending "blobs" rising into sulphide melt (Dowling et al 2004). C. Base of Cu-rich massive sulphide at the 
Oktyabrsky Mine, Talnakh, Siberia, showing sulphide injection along bedding planes in footwall argillite. Detached fragments of argillite ascend into melt in similar relationship to that seen at Silver Swan. Photo courtesy of N. Krivolutskaya, S Sluzhenikin and field trip leaders of the Noril'sk excursion at the $13^{\text {th }}$ International Platinum Symposium; photo from the field trip guidebook (Sluzhenikin et al, 2014). D. Sulphide injected into pillow basalt breccia approximately $1 \mathrm{~m}$ below base of massive sulphide ore shoot in the Moran Shoot, Long-Victor Mine, Kambalda. E, downwardinjected sulphide veinlets at the base of the Savannah (formerly Sally Malay) deposit in the Halls Creek Mobile Zone, Western Australia. F. Sulphide vein injection, Reid Brook Zone, Voisey's Bay, located $\sim 5 \mathrm{~m}$ directly below a $>10 \mathrm{~m}$ body of massive sulphide, emplaced sub-parallel to wall-rock fabric dipping roughly 30 degrees within the Tasuiyak Gneiss..

Figure 8. Schematic illustration of components of the crustal portion of an idealised magmatic plumbing system, showing a hypothetical sequence of events leading to the development of Norils' $\mathrm{k}$ style, Eagle-Kalatongke style and Voisey's Bay style settings for mineralisation. See text for full explanation.

Figure 9. Comparison of melting ranges for silicate and sulfide liquids for various pressures and water contents. Data Medard and Grove (2005) for silicates, Craig and Kullerud (1969) for sulfides based on the $\mathrm{Cu}-\mathrm{Ni}-\mathrm{Fe}-\mathrm{S}$ system. 
Table 1. Characteristics of komatiite-hosted vs mafic-hosted Ni-Cu-PGE sulfide deposits.

\begin{tabular}{|c|c|c|}
\hline Attribute & Komatiite-hosted deposits & Mafic intrusion-hosted deposits \\
\hline $\begin{array}{l}\text { Nature of host } \\
\text { silicate magma }\end{array}$ & $\begin{array}{l}\text { Low viscosity, high temperature, fast } \\
\text { cooling rate, wide melting range. }\end{array}$ & $\begin{array}{l}\text { High viscosity, low temperature, slow } \\
\text { cooling rates, narrow melting range } \\
\text { (relatively). }\end{array}$ \\
\hline $\begin{array}{l}\text { Nature of } \\
\text { sulfide ore } \\
\text { magma }\end{array}$ & $\begin{array}{l}\text { Ni-rich, } \mathrm{Cu} \text {-poor, extremely low } \\
\text { viscosity, narrow melting range. }\end{array}$ & $\begin{array}{l}\text { Relatively Ni-poor, Cu-rich, low } \\
\text { viscosity, wide melting range }\end{array}$ \\
\hline $\begin{array}{l}\text { Morphology } \\
\text { and geometry of } \\
\text { host body and } \\
\text { plumbing } \\
\text { system }\end{array}$ & $\begin{array}{l}\text { Elongate lava tubes or channels. } \\
\text { Predominantly horizontal, lateral flow } \\
\text { processes, vertical feeder dykes almost } \\
\text { never preserved. }\end{array}$ & $\begin{array}{l}\text { Tube- or funnel-shaped conduits, flow- } \\
\text { through sill-dyke complexes, blade- } \\
\text { shaped dykes. Ore formation within } \\
\text { long-lived, vertically extensive } \\
\text { recharged magmatic plumbing systems. }\end{array}$ \\
\hline $\begin{array}{l}\text { Relationship to } \\
\text { host rocks }\end{array}$ & $\begin{array}{l}\text { Thermal/mechanical erosion of floor } \\
\text { rocks. }\end{array}$ & $\begin{array}{l}\text { Thermal/mechanical erosion of floor } \\
\text { and roof rocks, abundant xenoliths and } \\
\text { intrusion breccias. }\end{array}$ \\
\hline $\begin{array}{l}\text { "Taxites" and } \\
\text { pegmatoidal } \\
\text { rocks }\end{array}$ & $\begin{array}{l}\text { Virtually unknown - equivalent may be } \\
\text { contaminated pyroxene-rich cumulates. }\end{array}$ & $\begin{array}{l}\text { Common "taxites" - contaminated, } \\
\text { vari-textured to pegmatoidal and locally } \\
\text { volatile-rich gabbros at intrusion } \\
\text { margins and within orebodies, common } \\
\text { association with minor hydrous silicate } \\
\text { phases. }\end{array}$ \\
\hline $\begin{array}{l}\text { Massive ore } \\
\text { disposition }\end{array}$ & $\begin{array}{l}\text { Usually planar, conformable at basal } \\
\text { contacts, may inject into floor rocks. }\end{array}$ & $\begin{array}{l}\text { Commonly cross-cut early marginal } \\
\text { rocks of host intrusion and adjacent } \\
\text { wall rocks. }\end{array}$ \\
\hline Breccia ores & $\begin{array}{l}\text { Rare - where found, due to melting of } \\
\text { floor rocks and gravitational floating of } \\
\text { detached xenomelts. }\end{array}$ & $\begin{array}{l}\text { Breccia ores common - normal Cu-Ni } \\
\text { sulfide intrusion/injection breccias, } \\
\text { rarely (as at Noril'sk) external Cu-Pd } \\
\text { rich explosively emplaced } \\
\text { breccia/skarn ores. }\end{array}$ \\
\hline $\begin{array}{l}\text { Fractionation of } \\
\text { sulfide ore } \\
\text { magmas }\end{array}$ & $\begin{array}{l}\text { Minor, manifest as subtle differences } \\
\text { between massive ores and } \\
\text { matrix/disseminated ores. }\end{array}$ & $\begin{array}{l}\text { Common, can lead to chemical and } \\
\text { mineralogical differentiation of entire } \\
\text { orebody at scales from metres to } \\
\text { hundreds of metres. }\end{array}$ \\
\hline
\end{tabular}




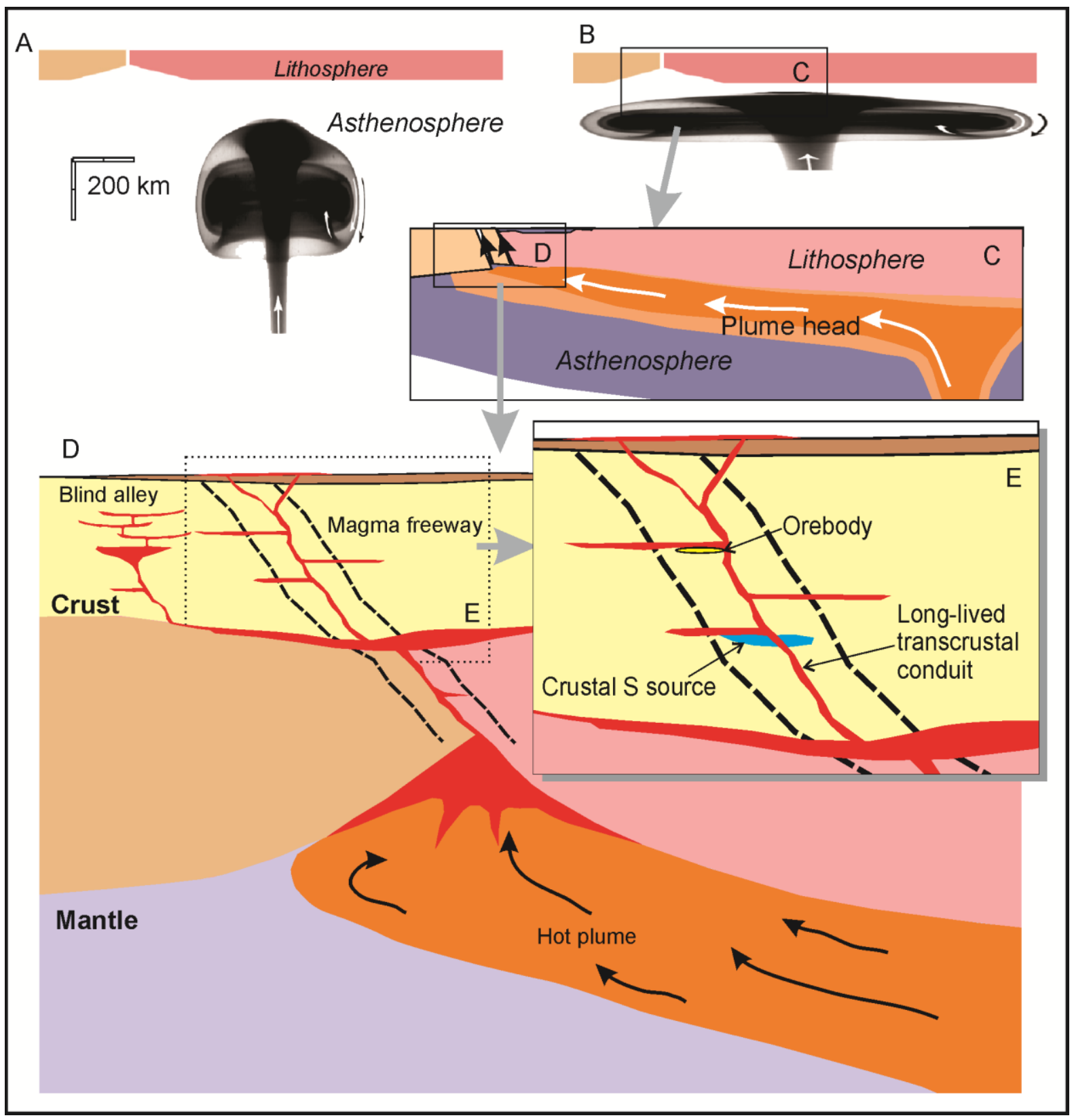



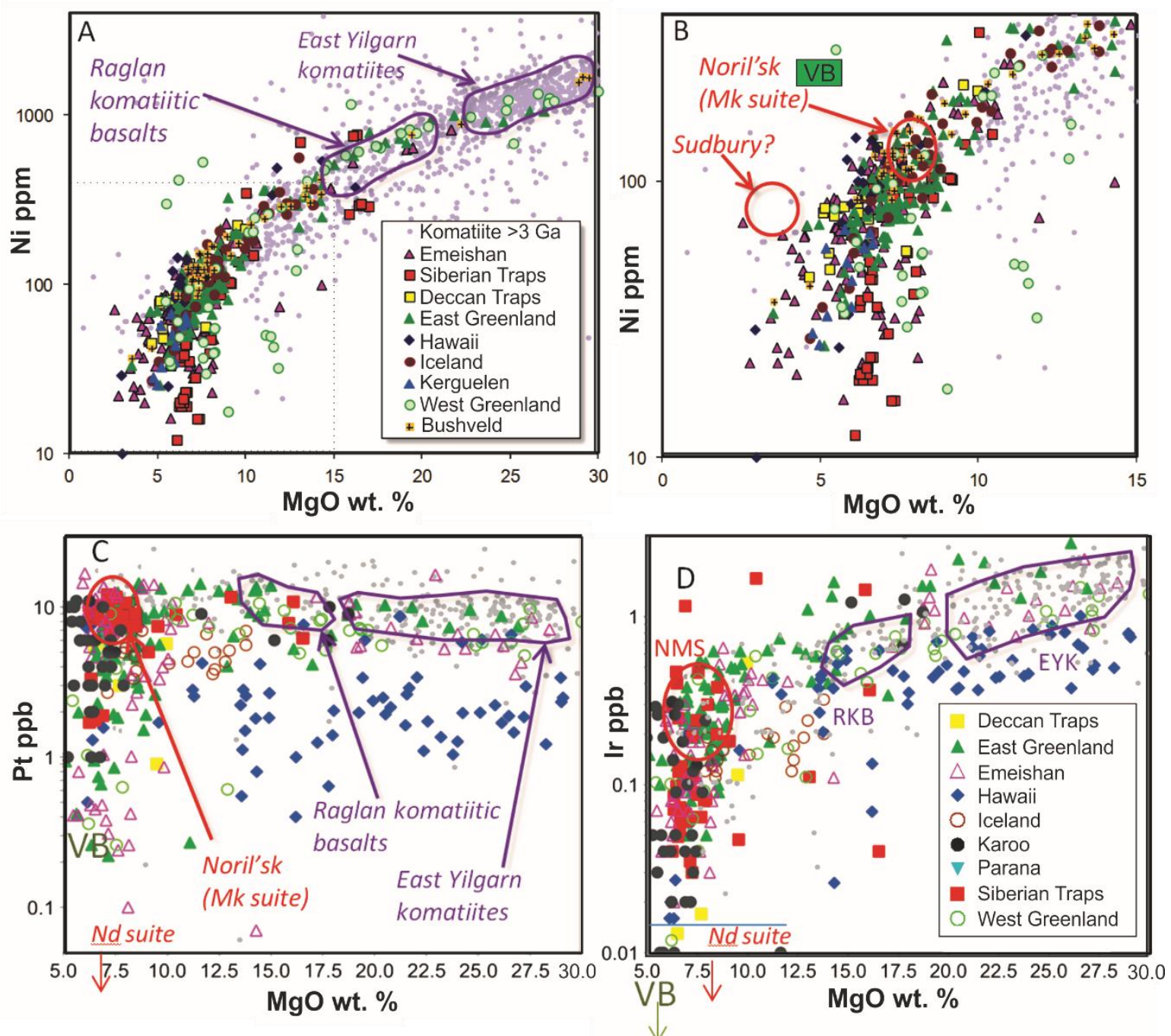


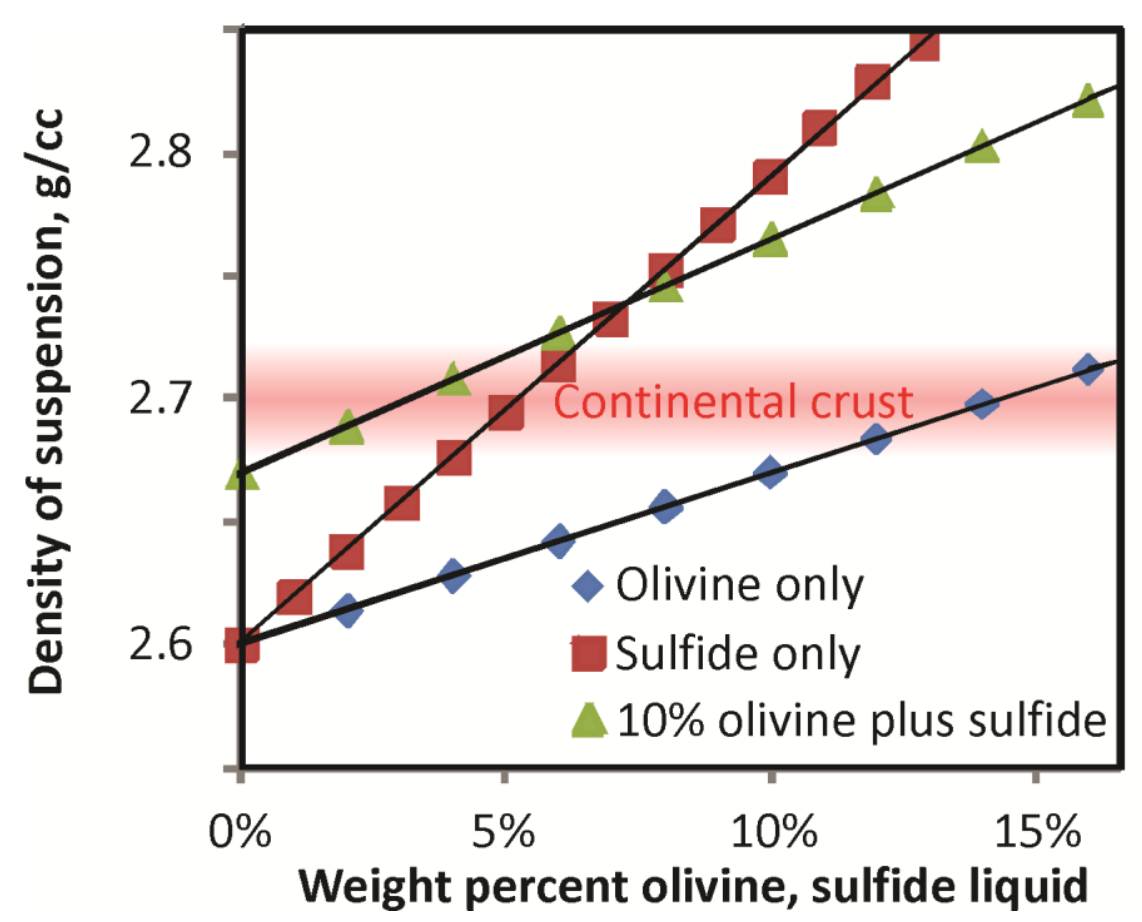



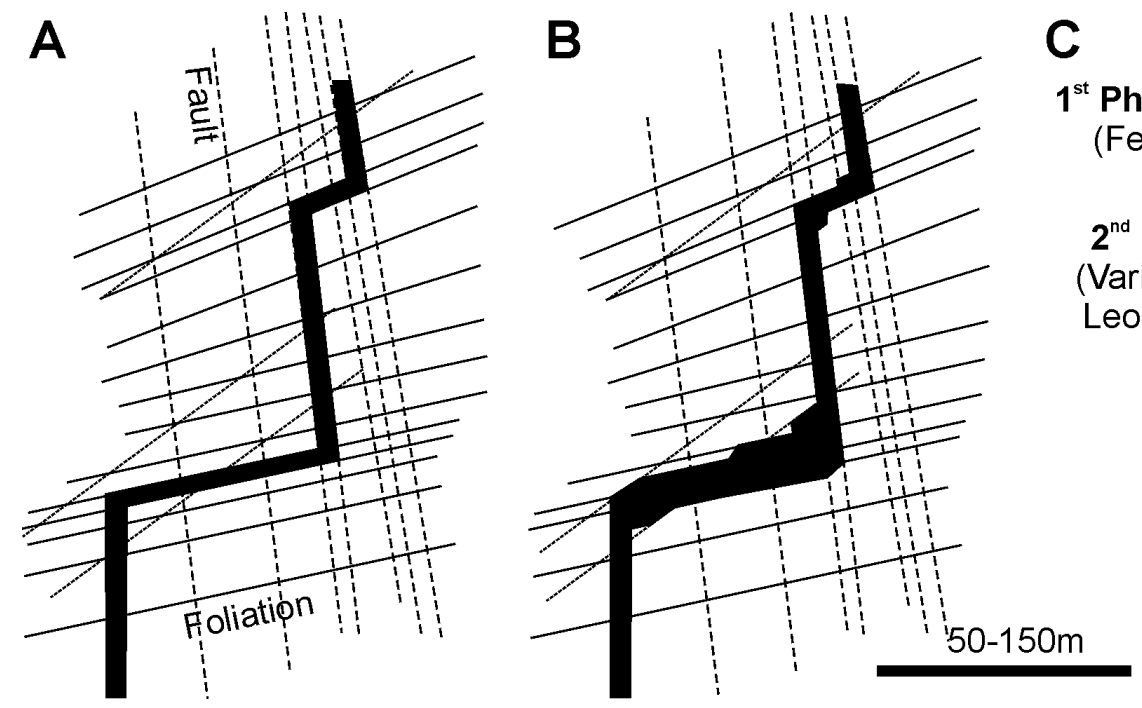

$1^{\text {st }}$ Phase Magma

(Feeder Olivine

$2^{\text {nd }}$ Phase Magma (Variable Troctolite/ Leopard Troctolite)

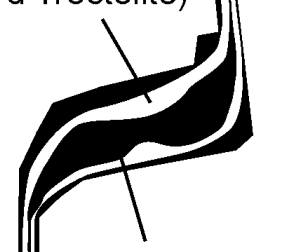

Final Phase Magma

(Breccia and

Massive Sulfide) 


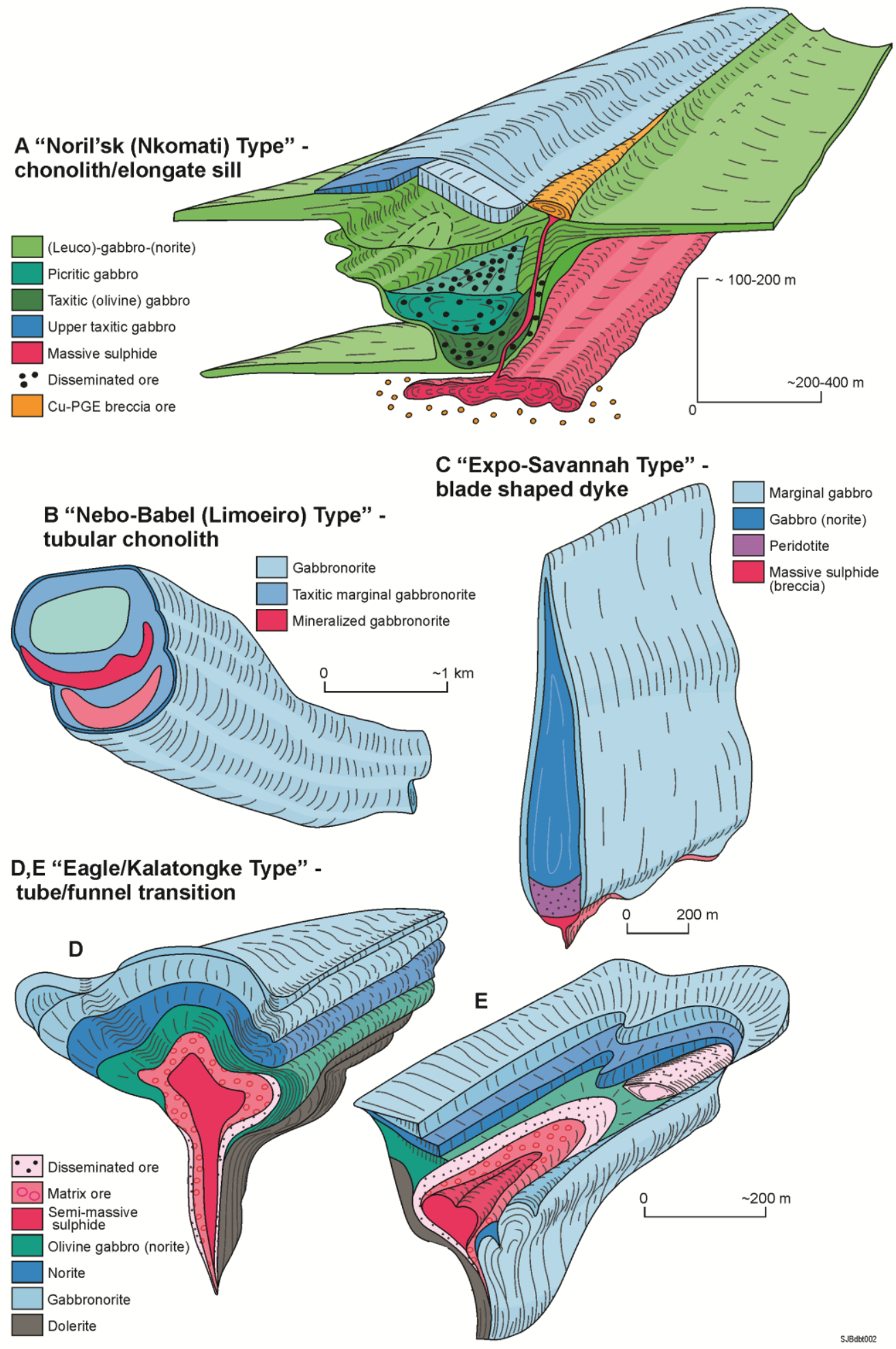



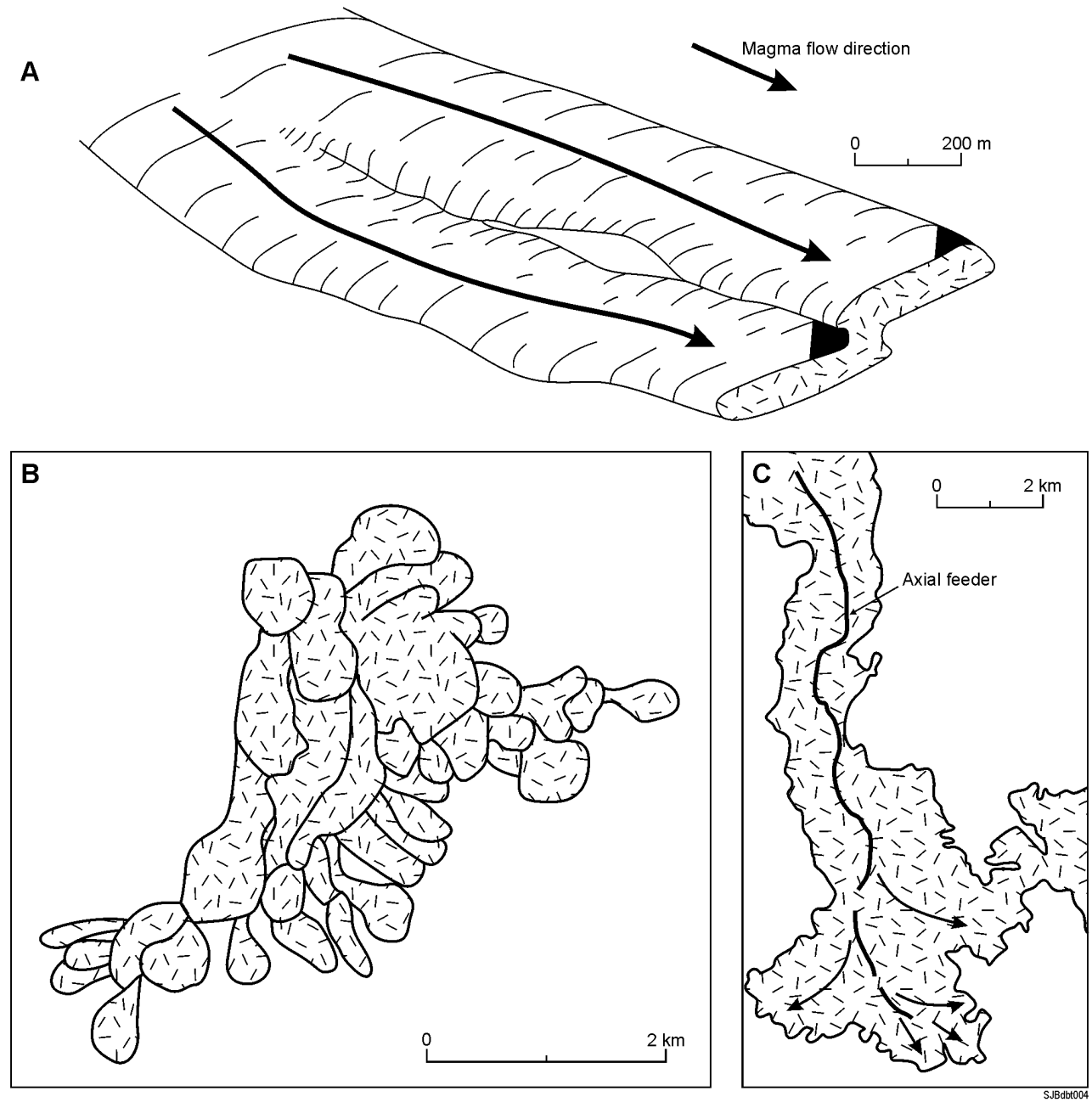

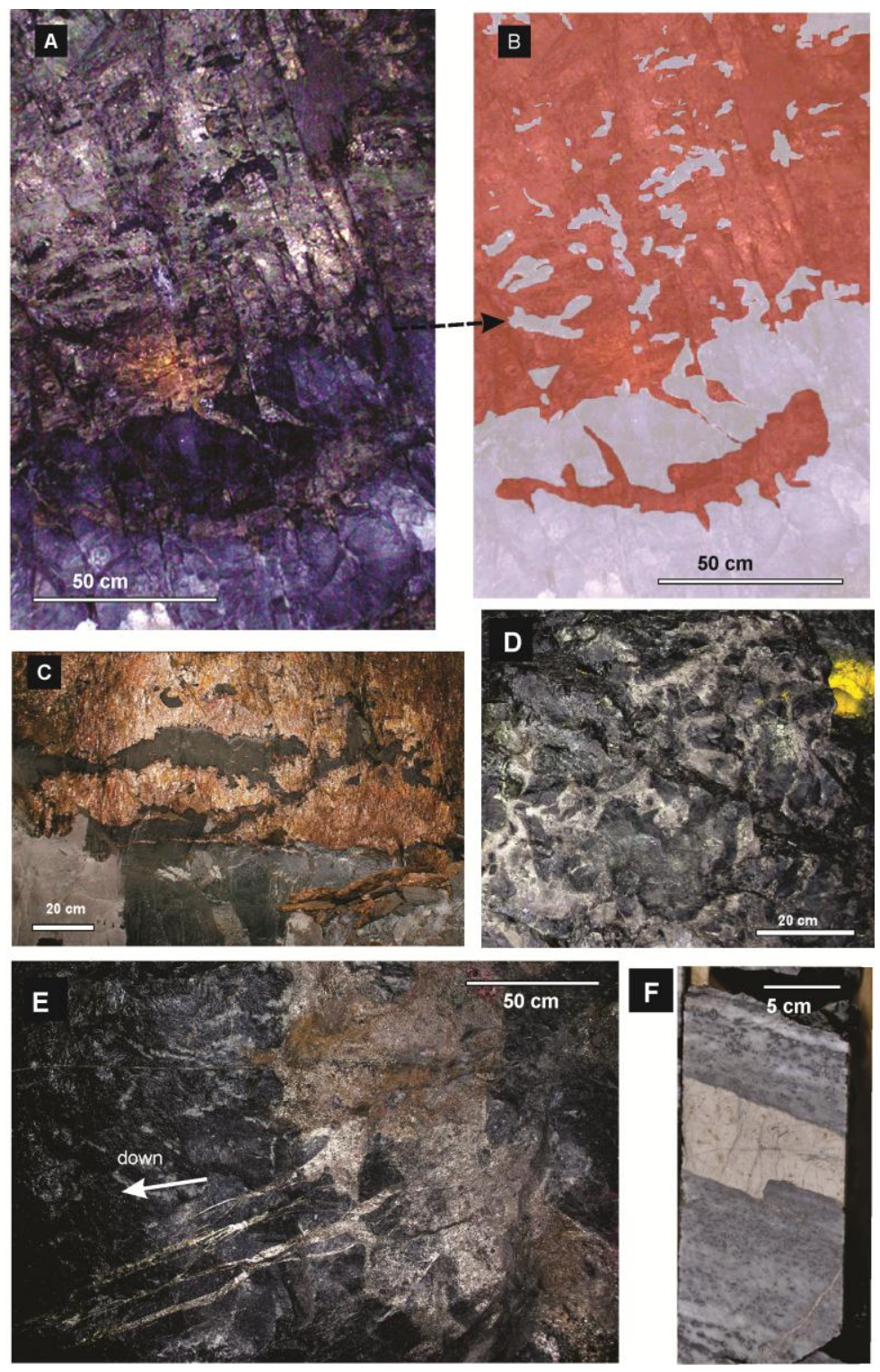


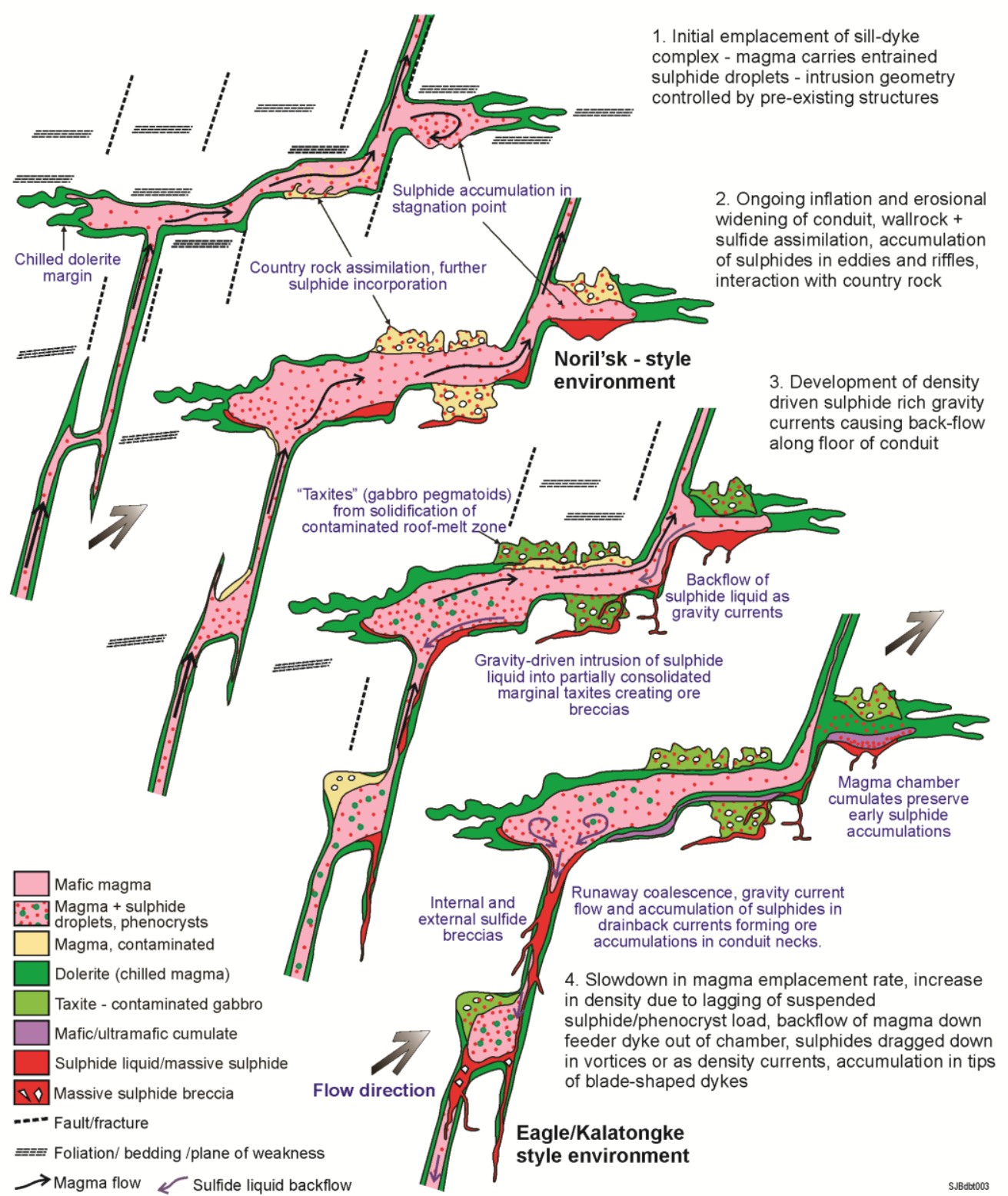




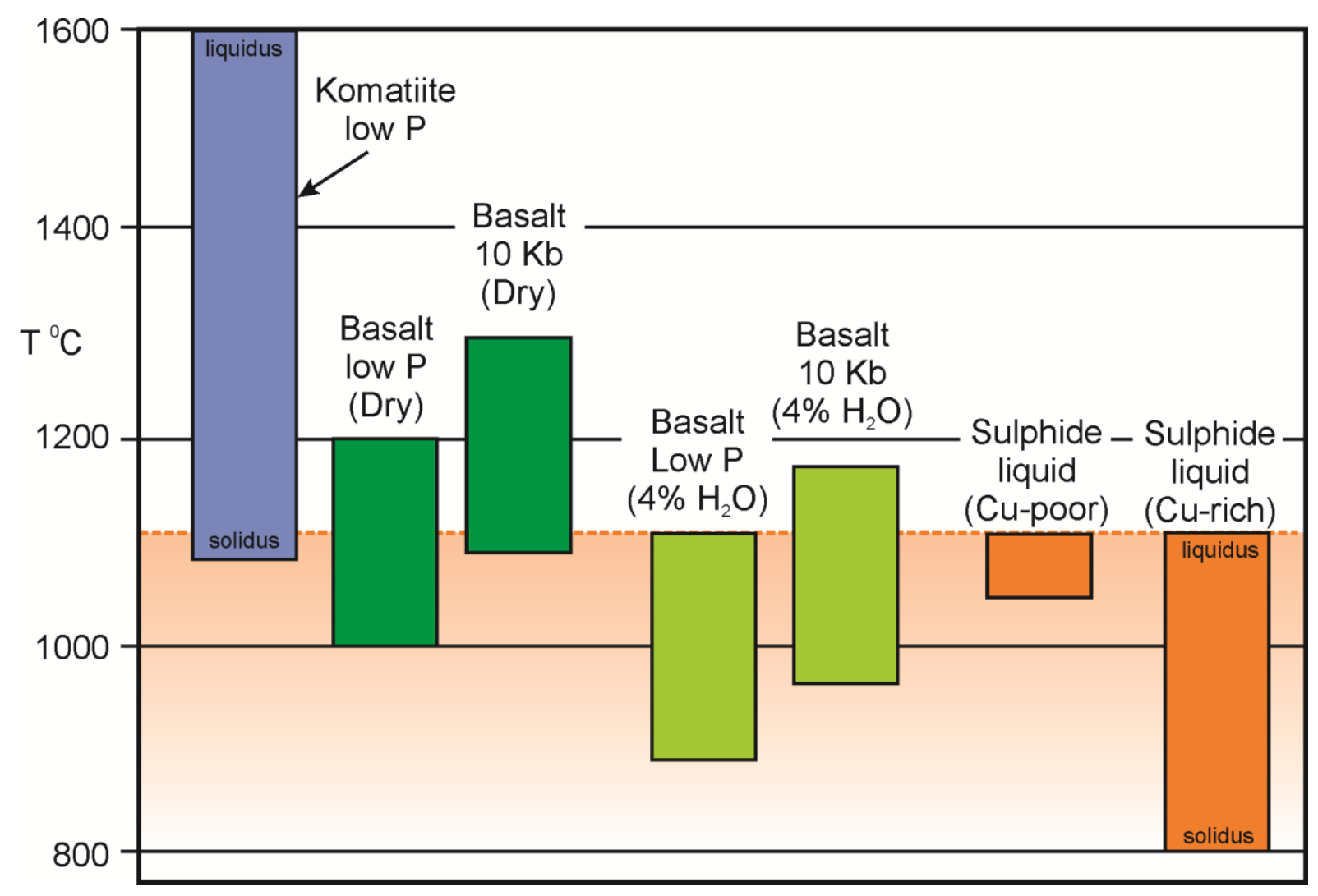

